\title{
Exploring the motives and practices of university-start- up interaction: evidence from Route 128
}

\author{
Niels van Stijn ${ }^{1,2} \cdot$ Frank J. van Rijnsoever ${ }^{1,3}$ • \\ Martine van Veelen ${ }^{2}$
}

Published online: 15 September 2017

(C) The Author(s) 2017. This article is an open access publication

\begin{abstract}
This paper explores the concept of university-start-up interaction (USUI) as a source of knowledge spillover and innovation. In doing so, we bring together literature on three broad mechanisms that enable knowledge utilization: education, new venture support, and university-industry interaction (UII), as we argue that USUI is a process in which all three are relevant. We first identify USUI practices and how universities and start-ups use these practices to achieve their objectives. Second, we study when the USUI process is mutually beneficial to both actor types in terms of resources. We develop a theoretical framework based on the objectives of the two actor types, the resource-based view, and three generic utilization mechanisms: education, creating new venture support, and UII. Empirically, 36 qualitative interviews were conducted with clean-tech start-ups, universities, and other experts, such as accelerators and incubator facilities in the Boston area, Massachusetts, USA, also known as "Route 128". After analyzing the resources exchanged during through 14 practices, we find that USUI is largely based on intangible resources. Second, the resources that universities transfer to start-ups mostly relate to organization and product development, but little to market development. Third, universities can strengthen their (entrepreneurship) education programs and knowledge utilization objectives through USUI, but there is little added value to fundamental research carried out by universities. Overall, we conclude that whether USUI is beneficial largely depends how organizations value their different objectives. Science-based start-ups are more likely to benefit from USUI, whereas start-ups close to market might be better off with other support programs. Universities with a strong focus on fundamental research benefit less from USUI than universities that are more diverse, applied, or have a strong focus on teaching and knowledge utilization. As such, our findings provide insight into the motives of USUI,
\end{abstract}

Frank J. van Rijnsoever

f.j.vanrijnsoever@uu.nl

1 Innovation studies, Copernicus Institute of Sustainable Development, Utrecht University, Heidelberglaan 2, 3584 CS Utrecht, The Netherlands

2 Climate-KIC, European Institute of Technology, Padualaan 8, $3584 \mathrm{CH}$ Utrecht, The Netherlands

3 INGENIO (CSIC-UPV), Universitat Politècnica de València, Valencia, Spain 
which enables policy makers and universities to promote knowledge utilization through USUI.

Keywords University-industry interaction · Entrepreneurship $\cdot$ Start-ups · Higher education $\cdot$ Technology transfer

JEL Classification I23 $\cdot \mathrm{L} 26 \cdot \mathrm{O} 31 \cdot \mathrm{O} 32$

\section{Introduction}

The utilization of knowledge created at universities plays an important role in the development of radical innovations, which contribute to the advancement of society and help to overcome grand societal challenges such as climate change (Elzen et al. 2004). However, knowledge utilization is often perceived to be lagging behind and universities are encouraged to devote more resources to this process (Grimaldi and Grandi 2005). To this end, universities have taken several actions, such as providing entrepreneurship education (Schulte 2004), establishing technology transfer offices (TTOs) and incubators, supporting university spin-outs (Siegel 2006), and performing collaborative research with industry (Adams et al. 2001; Medda et al. 2004). These knowledge utilization practices can be categorized in terms of three broad mechanisms: education, direct new venture support, and university-industry interaction (UII).

Start-ups are traditionally seen as an important source of innovation (Schumpeter 1942; Audretsch 2007), and these innovations are often considered a consequence of the utilization of knowledge from universities (Audretsch et al. 2012; Bellucci and Pennacchio 2015). This highlights the importance of the direct new venture support mechanism. Yet, the concept of the entrepreneurial university (Etzkowitz 2004) entails that also education and UII play a role in the process of academic knowledge utilization through new ventures. This process starts prior to the creation of new ventures in education and research programs, and can continue after the new venture is created through interaction between the university and the resulting start-up. Hence, all three mechanisms contribute to the process that we refer to as university-start-up interaction (USUI). The interaction between startups and universities is receiving increasing academic attention (see, for example, Boh et al. 2015; Calcagnini et al. 2015; Gubitta et al. 2015). Recent research shows that university based start-ups have a very high failure rate (van Geenhuizen and Soetanto 2009), this is especially true for start-ups that explore novel technologies (Soetanto and Jack 2016). Such findings cast doubt on the usefulness of USUI, as both the university and the start-up seem to gain little by interacting with each other. However, before such a conclusion can be drawn, we must first systematically understand the USUI process. To this end, three knowledge gaps deserve further attention.

First, in exploring USUI, it is important to consider exactly who is involved in the process. Knowledge utilization has been widely studied in relation to existing industry (for an overview see Rothaermel et al. 2007; Bozeman et al. 2013), as is generally the case in UII. However, these studies do not take into account that start-ups differ greatly from established firms: they have a stronger focus on generating product innovation (Ries 2011), they have a higher dependency on their sales from innovative products (Criscuolo et al. 2012), and they play an important role in exploring new technology markets (Almeida and Kogut 1997), but are more likely to lack the resources required to develop and market radical innovations successfully (Vohora et al. 2004; Bruton et al. 2010). As such, the interaction between universities and start-ups demands explicit academic attention. 
Second, to understand knowledge utilization, it is important to understand why actors engage in this process. For this we need to look at the incentives that the two different actor types receive from their own institutional contexts (Etzkowitz and Leydesdorff 2000). Universities are known to focus strongly on publications and scientific credibility (Latour and Woolgar 1979; Hessels and van Lente 2008), whereas start-ups focus on the creation of new organizations, products, and markets (Bhave 1994; Gaglio and Katz 2001). For this they need crucial resources that can be exchanged with other actors via interaction practices (Lin et al. 2009). Only if knowledge utilization contributes to achieving the objectives of all the actors involved can it become viable in the long term. Most current studies focus only on only one actor type (Rothaermel et al. 2007), but to assess if USUI is a viable process, it is important to look at how it affects the competitive position of both actor types involved.

Third, we need to understand how knowledge utilization takes place. The interaction between universities and start-ups has mainly been studied in the context of incubators (Hisrich and Smilor 1988; Rothaermel and Thursby 2005a, 2005b), or in a more descriptive sense of the entrepreneurial university (Etzkowitz 2003; Schulte 2004; Levie 2014), but the simultaneous use of all three mechanisms has not yet been systematically assessed. This is unfortunate as the extent to which the objectives of an actor are achieved is the result of a combination of all three mechanisms.

Therefore, this study aims to explore the conditions under which university-start-up interaction is mutually beneficial to both universities and start-ups in terms of resource acquisition. To this end, we first develop a theoretical framework based on the objectives for each actor type, their resource requirements, and the three utilization mechanisms underlying the process of USUI. Empirically, 36 qualitative interviews were conducted among clean-tech start-ups, universities, and other experts, such as accelerators and incubator facilities, in the Boston area, Massachusetts, USA, also known as "Route 128". We draw the overall conclusion that whether USUI is beneficial or not largely depends on how organizations value their different objectives. Science-based start-ups are more likely to benefit from USUI, whereas start-ups close to market might be better off with other support programs. Universities with a strong focus on fundamental research benefit less from USUI than those that are more diverse, engage in applied research, or have a strong focus on teaching and knowledge utilization.

Theoretically, this study is the first to explore USUI systematically as the interaction process between universities and start-ups from both sides, considering practices from all three utilization mechanisms. By taking this broader perspective, we demonstrate how universities and start-ups can help each other to achieve their objectives and contribute to understanding of the incentives for interaction among different actor types. This can enable policy makers and universities to promote knowledge utilization via start-ups.

\section{Theory}

This section develops a framework that serves as the basis for the data collection and interpretation in this study. First, building on extant literature, we provide a characterization of university and start-up objectives and the core activities deployed to attain these objectives, based on the incentives these actor types receive from their institutional environment. Second, we identify and categorize the resources that universities and startups acquire in the process of USUI, and how these resources contribute to the previously 
defined university and start-up objectives or activities. Third, we discuss the three knowledge utilization mechanisms and how they contribute to the process of USUI. Together, these theoretical concepts compose a framework of interpretation that allows for the understanding of the motives and benefits of USUI for both universities and start-ups.

\subsection{Start-up objectives and core activities}

The central endeavor in entrepreneurship is the establishment of a viable new organization, which Liao and Welsch (2008) define as "the temporal sequence of events or activities that occur as entrepreneurs create a new business" (p. 104). This connotation is also referred to as gestation (Reynolds and Miller 1992), organizational emergence (Gartner et al. 1992) and start-up (Vesper 1990). In this paper, we refer to this process, as well as the organizational entity involved in this process, as a start-up.

Analytically, a start-up aims to achieve three main objectives: organization development, technology and product development, and market development (Bhave 1994; Gartner and Vesper 1994; Gaglio and Katz 2001). These objectives are met by means of a set of core activities that take place at different moments in time (Bhave 1994; Liao and Welsch 2008). Together, these objectives and activities form the basis of incentives for USUI on the part of start-ups. The following list of objectives and activities is not exhaustive, but outlines the most important objectives and activities that new organizations need to achieve to develop a successful organization.

\subsubsection{Organization development}

Organization development encompasses structuring both the conceptual and physical attributes of the organization (Bhave 1994). The literature recognizes three activities as key to reaching this objective; (1) opportunity recognition, (2) business concept development and (3) organization creation.

Opportunity recognition relates to the decision to start a venture based on a specific opportunity to which the entrepreneur commits. This commitment follows a process of opportunity filtration, opportunity selection, and opportunity refinement (Gartner 1985; Bhave 1994; Gaglio and Katz 2001). After the entrepreneur has recognized a business opportunity and decides to exploit this opportunity, he or she will need to develop a business concept to do so. Business concept development refers to defining the business model and value proposition of the start-up. This involves action to define the business concept, and align customer needs and the entrepreneur's perception of those needs (Ardichvili et al. 2003; Delmar and Shane 2003). Organization creation is the activity of organizing of both the physical structure and the organizational processes that are required to produce and sell a certain technology at the core (Kilby 1971; Gartner 1985; Bhave 1994). This includes the establishment and accommodation of processes that aid in the development of a business concept (Ries 2011), as well as processes that enable the production and selling of the products or services that fulfill the customer needs as defined in the organization's business concept (Bhave 1994). Hence, the activity of organization creation takes place during and after business concept development. 


\subsubsection{Technology and product development}

Technology and product development may be considered a second objective of start-ups. In the development process of a functional product, two activities are key; (1) the development of the technology underlying a product and (2) the development of a product itself.

Technology development refers to the development of technology fundamental to the product. New technology-based start-ups that develop a new technology often need to perform research and development in laboratories to proof the technology concept (Bhave 1994). Successful technology development may support the entrepreneur's decision to exploit the business opportunities related to the technology (Park 2005). However, the availability of a technology itself is not an innovation. To exploit the business opportunity, the entrepreneur has to combine the technology with a market need; it requires the development of a product (Trott 2008). Product development comprises the transformation of a product idea into a physical product through the allocation of resources (Gartner 1985; Vesper 1990). Product development can build on technology development, but may also rely on the combination of existing technologies (Schumpeter 1942).

An important aspect of product development is the relationship between the entrepreneur, customers, and the market, as the entrepreneur can use information from the customer and the market to improve the product design (Bhave 1994). We discuss two activities start-ups perform in relation to market development and acquiring information about the market below.

\subsubsection{Market development}

Market development is the third objective start-ups need to fulfill. This includes a bidirectional interaction with the market (Gartner 1985). Two activities are requisite for market development; (1) reaching out to customers and (2) acquiring and responding to customer feedback.

Customer outreach relates to the process of acquiring (first) customers (Gartner 1985; Bhave 1994), in which start-ups have to overcome the supply and demand boundary by marketing. However, creating a customer base is not enough for the development of a successful business. Start-ups also need information regarding the needs of customers (Cooper and Kleinschmidt 1987). Customer feedback subsequently occurs as the start-up evaluates-and acts upon-feedback acquired from (potential) customer interaction (Gartner 1985; Bhave 1994). Sometimes firms need to revise product features by revising existing equipment. In other cases, an alteration of the business concept is required. Hence, customer feedback may contribute to the activity of product development.

\subsection{University objectives and core activities}

Traditionally, the two objectives of universities are to educate and to perform research (Göransson et al. 2009). However, universities also increasingly engage in knowledge utilization (Etzkowitz 2004), although this often seems at odds with the two traditional objectives. These three objectives are met by means of the performance of a set of core activities, which we discuss below. These activities take place at different moments in time. Even though this list presents a simplified view on the objectives and activities 
performed, they are useful for understanding the university's motives behind USUI as they form the basis of incentives for USUI on the part of universities and researchers.

\subsubsection{Education}

Education at the university generally takes place through undergraduate and graduate programs. Three activities can be distinguished that contribute to the objective of education; (1) the training of academic professionals, (2) training a high-quality workforce, and (3) training entrepreneurs. These activities receive input from the research activities performed by the university, in the form of knowledge.

Training academic professionals concerns the preparation of students for a faculty career (Austin 2002). This activity includes education concerning the roles and responsibilities of faculty, such as teaching, managing research projects, and the development of academic skills (Austin 2002; Göransson 2009). However, not all university students will make career in academics. Some may also pursue a job within industry (Hager and Holland 2007). Training a high-quality workforce adds the education of high-level practitioners are able to fulfill a role within industry (Göransson 2009). Training of a high-quality workforce can be seen as an indirect technology transfer activity, providing academically educated and specialized personnel to industry (Carayannis et al. 1998). Furthermore, universities also deploy programs that consider their students as job creators; the education of entrepreneurs (Schulte 2004; Levie 2014). Training entrepreneurs, then, encompasses the transfer of knowledge to students, relevant to developing a business through endeavors such as business school programs and entrepreneurship courses (Schulte 2004). By these means, students are trained to start new ventures (Pirnay and Surlemont 2003).

\subsubsection{Performing research}

Concerning the objective of performing research, we discern two types of activity; (1) performing more generic or fundamental research activities, and (2) performing applied research activities (Lee 1996).

Performing fundamental research summarizes the act of study with a basic orientation in science and engineering from a perspective of developing greater knowledge and understanding of subjects without a specific application in mind (Gibbons et al. 1994). This knowledge is typically disseminated by means of educating students and publishing scientific writings without any direct commercial interest (Audretsch and Lehmann 2005). Hence, the objectives education and research are connected as the research objective provides input for the education objective. Universities however, do not perform solely fundamental research. Universities may also perform a more user-oriented or applied type of research. Performing applied research comprises proprietary research with strong practical implications, such as contract research on behalf of private enterprises and public authorities (Göransson 2009).

\subsubsection{Knowledge utilization}

To need to perform more relevant research and utilize this research is described in various models (Hessels and van Lente 2008) like the development of 'Mode 2' research (Gibbons et al. 1994; Nowotny et al. 2003), and the Triple Helix (Etzkowitz and Leydesdorff 1998, 2000). All these models argue that academia needs to become more accountable for 
the research it produces with public funds, and that this research must be increasingly relevant (Hessels and van Lente 2008).

From the knowledge utilization objective, the following two activities generally follow; (1) research commercialization and (2) start-up support.

Research commercialization entails the transfer of academic knowledge to industry through efforts such as academic spin-off, spin-out, and spillover (Etzkowitz 2004). Respectively, this means that university research is commercialized (1) through the formation of a start-up (Link and Scott 2005), (2) using the technology license of a signed invention to create a new company for exploitation of the license (Di Gregorio and Shane 2003), or (3) directly with firms in industry through contract research or joint research projects (D'Este and Patel 2007). Consequently, research commercialization is strongly connected to the research activities of the university, as they provide the input for commercialization. Start-up support, on the other hand, does not build solely on the output of research activities, but facilitates new venture creation by means such as university-supported incubation practices (Mian 1996), aid in patenting, and the establishment of science parks (Link and Scott 2005). Such practices are often oriented toward both the university community and society.

\subsection{Resource requirements}

To perform the activities described above, both types of actors require resources. For startups, the ability to acquire and develop resources has shown to be crucial for survival (Dollinger 1999). In particular, knowledge about how do to business and access to social networks are considered important (Bruneel et al. 2007; Eveleens et al. 2017; Van Weele et al. 2017).

As the environment in which universities operate has become more competitive and market-like (Powers and McDougall 2005), universities have put more effort into acquiring research funding, high quality faculty and the brightest students. Consequently, some universities strive to increase the output of publications (contributing to the advancement of academic ranking) and strengthen the researchers' competitiveness for research grants through cooperation (Latour and Woolgar 1979).

Generally, these resources can be divided into two categories: tangible resources reflect the assets of an organization with an actual physical existence (Galbreath 2005), whereas intangible resources reflect the non-physical assets of an organization (Kristandl and Bontis 2007). The following list of resources is not exhaustive, but outlines the most important resources that universities and start-ups require for attaining their objectives. We base this categorization on Van Weele et al. (2017), who used it to understand the resource needs of clean-tech start-ups at university incubators. Other studies have taken a similar approach (e.g. Albert and Gaynor 2000; McAdam and McAdam 2008). We first provide a definition of each resource type. Subsequently, we discuss the resource in the context of the objectives of the university, respectively start-ups.

\subsubsection{Tangible resources}

- Financial capital encompasses all monetary resources available for the deployment of organizational activities (Barney 1997). Financial capital is critical for conducting research within the university. Besides federal funding, universities look for other sources of funding, which has become essential for today's universities (Etzkowitz et al. 1998). Start-ups often depend on external financial capital, especially in 
technology and product development and organization creation (MacMillan et al. 1987; Bhave 1994).

- Human capital is the aggregation of the labor force, differentiated based on educational training, entrepreneurial experience, working experience, and ambition (Davidsson and Honig 2003). For the university, human capital is essential for the quality of education and research (Powers and McDougall 2005). For start-ups, human capital with expert knowledge and talent is an important resource for commercializing a cutting-edge technology (Powers and McDougall 2005).

- Physical capital reflects the hardware used by organizations, such as the organization's facilities and equipment, and the availability of raw materials (Barney 1991). For universities, the use of expensive or unique laboratory equipment can be essential to perform certain types of research (Thorsteinsdóttir 2000). High-tech start-ups often require a place to work from or need specialized equipment for technology and product development (Roessner et al. 1998).

\subsubsection{Intangible resources}

- Business knowledge comprises the information and experience required for running a business (Vohora et al. 2004). Business knowledge contributes to research commercialization in universities as it helps to transform research outcomes into a viable business (Powers 2003). For entrepreneurs, business knowledge is essential in opportunity recognition, business concept development, organization creation, promoting products across the supply and demand boundary, and customer feedback (Chan and Lau 2005).

- Technical or scientific knowledge refers to information and experience with a specific technology, and can be a result of academic research (Rosenberg and Nelson 1994). Developing technical or scientific knowledge in scientific publications is one of the core activities of universities (Hessels and van Lente 2008) and is considered a source of its competitive advantage (Van Rijnsoever et al. 2008). In start-ups, technical knowledge allows effective exploitation of the potential of technology, the interpretation of new information (Cohen and Levinthal 1990), and determination of the optimal product design (Rosenberg 1994).

- Market knowledge covers the information and experience enabling organizations to make more accurate predictions of the commercial opportunities in their environment so that they can take strategic action (Cohen and Levinthal 1990). Knowledge of the market value of specific scientific discoveries can increase a university's ability to determine the commercialization potential of a technology (Shane 2000). Knowledge of customer demands, customer preferences, and the market is valuable for start-ups regarding product development and marketing (Shane 2000; Von Hippel 2007).

- Social capital can be defined as 'the goodwill that is engendered by the fabric of social relations that can be mobilized to facilitate action' (Adler and Kwon 2002, pp. 17). It 'comes about through changes in the relations among persons that facilitate action...it exists in the relations among persons' (Coleman 1988, pp. 100-101). Social capital aggregates the organization's potential to extract benefits from its network and social structures (Davidsson and Honig 2003). Social capital can enable start-ups to 'access' resources provided by third parties, and can therefore compensate for an initial lack of essential resources internally. 
- Credibility of actors has been extensively studied and debated in the past (Hovland and Weiss 1951; Pornpitakpan 2004; Sternthal et al. 1978). However, the concept is rarely defined explicitly. Authors refer instead to elements of the concept, commonly trustworthiness, expertise and reliability. We follow the suggestion by Van Rijnsoever et al. (2014), and define credibility as the trustworthiness, reliability, and expertise of an actor. Start-ups in particular, suffer from a shortage of credibility as they often lack a track record (Vohora et al. 2004). Based on a relationship with an external actor, credibility allows start-ups to access resources such as other networks and financial capital (Shane and Cable 2002). Scientific credibility helps universities to earn recognition for, sustain, and expand their practices (Latour and Woolgar 1979), such as those related to teaching, research, or entrepreneurship.

\subsection{Knowledge utilization mechanisms}

In the USUI process one can distinguish several mechanisms through which the resources are transferred. Based on the extant literature we identify three knowledge utilization mechanisms; education (Saxenian 1996; Etzkowitz 2004), new venture support (Rasmussen and Wright 2015; Soetanto and Jack 2016), and university-industry interaction (UII) (Meyer-Krahmer and Schmoch 1998; Perkmann et al. 2013; Frank J. Van Rijnsoever et al. 2008). These mechanisms are not exclusively part of the USUI process, but USUI encompasses all three. The three mechanisms form broad categories, under which various practices can be categorized through which the resources (Sect. 2.2) that contribute to the activities of both actor types (Sect. 2.1). We identify these practices in the results, and show in what manner they make their contribution to the goals of both actor types.

\subsubsection{Education}

Education is an indirect utilization mechanism (Saxenian 1996; Etzkowitz 2004), as the fundamental knowledge is transferred by delivering specialized graduates to industry (Carayannis et al. 1998). In addition, universities can transfer knowledge on developing a business through entrepreneurship education (Schulte 2004), thereby supporting graduates in starting a new venture (Pirnay and Surlemont 2003). Education is important as the employment of graduate students is one of the most frequently used types of interaction between firms and universities (Schartinger et al. 2001). Moreover, ideas for new business are often formed during university education (Åstebro et al. 2012) and entrepreneurship education can be used to support business entry (Gartner et al. 1992). Despite its importance, it has received the least attention in the utilization debate.

\subsubsection{New venture support}

A utilization mechanism that has received much academic attention, is new venture support (Perkmann et al. 2013; Rothaermel et al. 2007). New venture support entails directly supporting the creation of university spin-offs in the form of new ventures (Mueller 2006; Rothaermel et al. 2007). University research is commercialized by building a new business from scratch (Clarysse and Moray 2004). Uninhibited by past structures, start-ups are able to generate radical innovations, introducing new products or even creating entirely new markets (Audretsch 1995). Supporting the creation of new ventures is important as building a new organization requires specific resources (Rothaermel and Thursby 2005a) 
and entails entrepreneurial learning processes (Scillitoe and Chakrabarti 2010; Wang and Chugh 2014). Both can be supported by the university (McAdam and McAdam 2008). The support of new ventures or academic spin-offs belongs to a relatively new conceptualization of the university, often referred to as the entrepreneurial university, in which the university is framed as an entrepreneurial organization (e.g. Bramwell and Wolfe 2008).

\subsubsection{University-industry interaction}

The commercial engagement of the university is considered an outcome of the wider concept of academic engagement. Perkmann et al. (2013 p. 424) define academic engagement as "knowledge- related collaboration by academic researchers with nonacademic organizations". Academic engagement has affected the role of the university in knowledge production. This changing role of the university in knowledge production has been described in the literature on modes of knowledge production (Baber et al. 1994) and the triple helix thesis (Etzkowitz and Leydesdorff 2000), which emphasize continuous interaction between industry, policy and academia. A utilization mechanism that stems from academic engagement, and that we consider relevant for USUI, is university-industry interaction (UII). University-industry interaction entails the knowledge transfer and research support relationships of universities, primarily with existing industry (Santoro and Chakrabarti 2002). Established firms have the resources and market power to make radical innovation successful (Chandy and Tellis 2000), but are often inhibited by their own existing routines (Becker 2004) and internal inertial forces (Hannan and Freeman 1984). UII is important as start-ups still need access to resources after venture creation, such as specialized equipment, knowledge, social capital, and legitimacy, which are crucial for firm survival (Van Weele et al. 2017). Interacting with universities can provide access to these resources (Santoro and Chakrabarti 2002).

\section{Methods}

\subsection{Description of the case}

We study the USUI process around clean-tech in the greater Boston area in Massachusetts, or as it is informally known, "Route 128 ". Clean-tech consists of "a diverse range of innovative products, services and solutions that optimize the use of finite and renewable natural resources for long-term commercial and environmentally sustainability" (Ernst and Young 2011, p. 6, in Davies 2013). Clean-tech is increasingly receiving attention from both politics and academia (Caprotti 2012), and is considered an area in which knowledge utilization and innovation is necessary (June and Fargo 2013). Furthermore, this industry includes a wide variety of societal actors and scientific disciplines that serve a common objective, making clean-tech a typical "Mode 2" technology (Gibbons et al. 1994). Altogether, clean-tech is an outstanding empirical example for the study of USUI.

Massachusetts is a leading US state on clean-tech policy, having strong regulatory mandates and powerful incentives in place for clean-tech development. The region is known for clean-tech leadership in early-stage technology-based firm development, combined with a high capital attraction. In particular, the Boston area shows a high density of start-ups oriented to high-tech and active in the clean-tech industry (June and Fargo 2013), and also offers a large diversity of universities that show continuous interest in the 
clean-tech industry (June and Fargo 2013). This includes top universities, such as Harvard and MIT, but also smaller universities, such as Babson College and Olin College. Based on these characteristics we expected to find a many instances of USUI. This makes the Boston area a suitable location for the study.

\subsection{Data, data collection and measurements}

The primary data for this study were acquired by means of 36 semi-structured on-site interviews, which enabled the researchers to gather in-depth information, and created the possibility for further clarification and explanation of concepts. The interviews took 40 min on average.

Data were gathered from entrepreneurs (13), university representatives (9), and other stakeholders (14) considered experts in the field of new firm creation and universityindustry interaction (such as incubator managers, managers of accelerator programs, etc.). "Appendix 1" presents an overview of all respondents. The respondents were identified using web queries, formal and informal introductions, and referrals from earlier interviews. To increase the likelihood of theoretical saturation, the sample includes representatives from start-ups in different stages of maturity, representatives with various responsibilities from a variety of universities, and a large variety of other stakeholders.

Three types of interview schemes were used: one for the entrepreneurs, one for university representatives, and one for incubator managers and other stakeholders. The interviews were structured as follows. First, several background questions were posed. Entrepreneurs were asked to give a brief introduction to themselves and their firm. Representatives from universities and incubators were asked to give a brief introduction and to define their main purpose and core activities. Second, the interviewees were asked to define if and why interaction takes place between the actors, from their own perspective. This interview section aimed to derive an overview of the different interaction practices used in the process of USUI, the organizational activities that benefit from it, and the resources acquired. Further questions aimed for a more in-depth understanding regarding the methods used for interaction, the formal characterization of interaction, the interaction frequency, and how the interaction was established. In conclusion, the interviews focused on the conditions under which USUI is successfully deployed. The interview scheme was refined and updated if new concepts or information surfaced during the interview process. An overview of the final interview schemes is provided for in "Appendix 2". All interviews were digitally recorded and transcribed verbatim. Data were collected until theoretical saturation was achieved, meaning no new concepts emerged (Bryman 2013).

\subsection{Data analysis}

Prior to coding and analysis, a distinction was made between data from entrepreneurs, university representatives, and third party representatives. After this differentiation, qualitative coding was used to analyze the data. An inductive approach was adopted, but the connection between data and theory was constantly monitored using the coding process of Corbin and Strauss (Corbin and Strauss 1990). In doing so, cross-actor patterns could be discovered.

Accordingly, the data coding process was divided into two steps. In the first steps of the analysis we broke down the data analytically. We read the interview transcripts to inductively identify concepts that could explain the engagement of both actor types in USUI. Next, we identified relevant codes by means of open coding (Corbin and Strauss 
1990). Segments from the transcripts were labelled with 'in vivo' terms used by the interviewee as to minimize researcher subjectivity and bias. We then combined synonym codes into 'first order categories' (Gioia et al. 2013).

We relied on these open and first order codes to allow distinctive USUI practices to emerge from the data. It also provided characteristics of the Boston-entrepreneurial ecosystem. These practices and characteristics served as 'second order categories' (Gioia et al. 2013), which allowed us to relate first order codes with the USUI practices and ecosystem characteristics. Doing so provided insight in how the distinct practices and ecosystem characteristics of 'paying it forward' and the ecosystem's diversity contributed to the actor's objectives. An example of the data structure is provided in Table 1.

In the second step, we related the first order codes, associated with the previously identified USUI practices, to the concepts that were derived in our framework: the objectives of collaboration, the resources shared, and the utilization mechanism at work. The relationships between the USUI practices and these theoretical concepts were categorized in a table. We used this table to identify the higher-order relationships about the benefits of USUI for both actor types. These relationships were used to answer our research question.

Coding and data analysis were carried out using NVIVO, a qualitative analysis software program that is designed for the systematic analysis of qualitative data. NVIVO records all methodological steps taken and all handlings can be traced back, minimizing the researcher's personal bias. Moreover, emerging interpretations and findings were discussed with the entrepreneurs, university representatives and other relevant stakeholders during the process of data analysis as a form of 'member validation' (Lincoln and Guba 2013), which resulted in feedback and validation of our findings. This vigor increased the reliability of our findings. Additionally, during the entire process, we compared our results to what is already known from the current academic literature.

\section{Results}

We first discuss the context of the Boston start-up ecosystem related to USUI. Next, we provide an overview of the USUI practices that were identified. Finally, we relate the practices to our theoretical categories.

\subsection{The Boston ecosystem}

Although the general Boston entrepreneurial ecosystem is not as renowned as Silicon Valley, it has generated a diverse set of start-ups with hundreds of millions of dollars of revenue in software, life sciences, robotics, and materials industries (Marmer et al. 2012). These successful start-ups are located in the vicinity of universities, which supply them with talent and knowledge; "...every September there is a new flood of students in that are bringing in new ideas in, and then every June some go out. So, there is constant turnover." (O7). In addition, there are many different programs and facilities that aim to support a specific stage of start-up development. Besides support organizations that specialize in a specific development stage, the Boston ecosystem also houses start-up support organizations that specialize in sector specific start-up support. "The diversity of industries in the Boston ecosystem can be explained as each of these supporting organizations provide a different type of support, tailored towards a diversity of industries, enabling entrepreneurs 
Table 1 Data structure

\begin{tabular}{lll}
\hline $\begin{array}{l}\text { Second order } \\
\text { category }\end{array}$ & First order category & Segment example \\
\hline
\end{tabular}

Paying it forward A culture of paying it forward strongly relies on the past and future presence of entrepreneurship

Entrepreneurship MBA courses help to spot opportunities courses

\section{Academic} consulting
Universities stimulate student entrepreneurs to approach faculty for advice

Faculty is financially compensated by start-ups for advisory work

Engineering faculty provides voluntary technical advice to start-ups, as they like to share their know-how "because there has been so much entrepreneurial activity here historically, I think that culture has evolved over time just out of people helping one another and then wanting pay it forward and help someone else." (O2)

"So, if you look at how the university funds itself it's by connecting to those people. And the bulk of that money comes from the entrepreneurs, primarily because they tend to produce great wealth that they have personal control over." (U1)

" Getting people in a position where they can see the opportunity, this part of the educational process." (U2)

"we have what we call a peer advisory group here at the entrepreneurship center which consists of many, many different entrepreneurs from the ecosystem who are currently involved with startups who developed and sold, successful startups and they act as mentors to the current students. " (O3)

"Have you guys figured it out how much the friction is going to detract from this wonderful efficiency that you've got? Why don't you go see Professor So and So, the expert on seals and have him tell you what the problems are? Then come back and then we'll see whether you have the return on investment and the proper economics to make this engine as a worthwhile development." (U3)

"a lot of times companies bring on these technical advisors and their giving them equity which is something that's cheap and easy to give out at the start but can end up being very expensive." (E2)

"I think with especially engineering professors, if they see that you are solving a new problem. I get they are more than willing to give you a couple of minutes of their time or write you a detailed email back about what they know or where to look, or even meet with you. They just like to share their knowledge; put to use what they know." (E3) 
Table 1 continued

\begin{tabular}{lll}
\hline $\begin{array}{l}\text { Second order } \\
\text { category }\end{array}$ & First order category & Segment example \\
\hline $\begin{array}{l}\text { Collaborative } \\
\text { research }\end{array}$ & $\begin{array}{c}\text { In collaborative research efforts, start-ups } \\
\text { experience the university to have a } \\
\text { slower working pace }\end{array}$ & $\begin{array}{l}\text { "they were subcontracted out part of our } \\
\text { research. I think those were more } \\
\text { challenging in the sense that it was a fee } \\
\text { for service and there are, you know, } \\
\text { sometimes we found the academic } \\
\text { partners were not as fast and } \\
\text { entrepreneurial as we would have hoped } \\
\text { and they are burdened with a large } \\
\text { overhead, for example." (E4) }\end{array}$ \\
& &
\end{tabular}

to find a place with the best 'fit'. “... when you find you don't fit in one, you can flow to the other." (E5). Last, the high number of support organizations also generates a lot of interaction between actors. "...it's like atoms hitting each other, there is so many different ways that all these people could bump into each other, so that you finally find what you are looking for." (O8). This leads to a highly diverse ecosystem, which makes founding their business in Boston attractive.

Additionally, a culture of "forward paying" (Ready 2012) enables the founding of successful companies from the large pool of nascent entrepreneurs in the area. Actors in the ecosystem support start-ups, but it is expected that when these start-ups become successful companies, they will show their gratitude for this support. We found that this culture supports USUI as Boston universities build on this assumption when supporting (donating time and money) entrepreneurs "There is just this kind of willingness to help people out and to sit down and talk with someone, and give them your time to help them." (O1). Once successful, the entrepreneur can return the favor by becoming a mentor for a new start-up or by giving a financial donation.

\subsection{Identifying USUI practices}

In total, we identified 14 USUI practices (see Box 1). They cover all three utilization mechanisms (see Fig. 1). Some are already well known from the literature. We list them here, because they are included in our second step of analysis. "Appendix 3" gives a detailed description of each practice.

We did not find any evidence of post-graduate educational practices such as professional workshops or courses taught in the workplace as examples of USUI practices (Rahm 1994). The reason for this is that the entrepreneurs are often students or recent graduates of the university, which lowers the need for post-graduate teaching. The interviews also presented some difficulties regarding the successful implementation of USUI practices. In line with findings on UII (Kaufmann and Tödtling 2001), the major barrier to USUI is that universities and start-ups operate at different paces. Whereas universities are strongly focused on generating accurate knowledge and take time to do so, start-ups have shorter time cycles and are more application-oriented. When actively collaborating, this difference between the actor types implies different work speeds. Combined with a large overhead, 


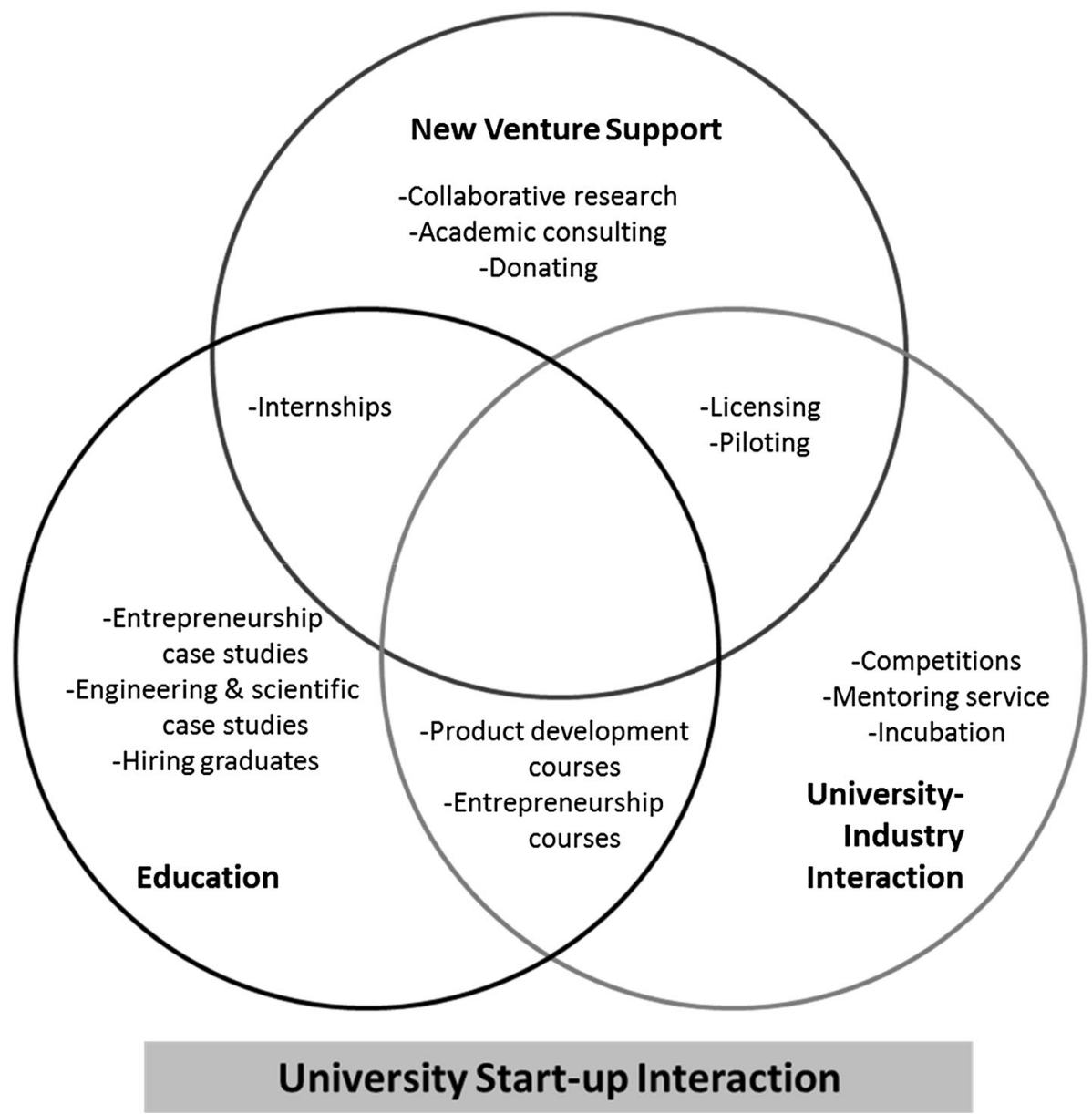

Fig. 1 USUI practices and knowledge utilization mechanisms

universities may therefore become a partner too costly for start-ups if any payment is involved. "I think those were more challenging in the sense that it was a fee for service and there are, you know, sometimes we found the academic partners were not as fast and entrepreneurial as we would have hoped and they are burdened with a large overhead." (E4). Moreover, some universities view interacting with start-ups as problematic because their dynamic nature makes it difficult to establish a long-term relationship. To overcome this barrier, start-ups use their pre-existing relationships with the university. This makes the interaction more informal, and allows for a more tailored treatment. "So that I think works more smooth because there's already a pre-existing relationship. And the employee at $[\ldots]$ knew the professor and then it was more informal." (E4).

\subsection{Relating USUI practices to resources, objectives and activities}

In Table 2, we categorize each USUI practice according to the utilization mechanism, the associated resources, and the objectives and activities to which it is related: " $\mathrm{x}$ " indicates 


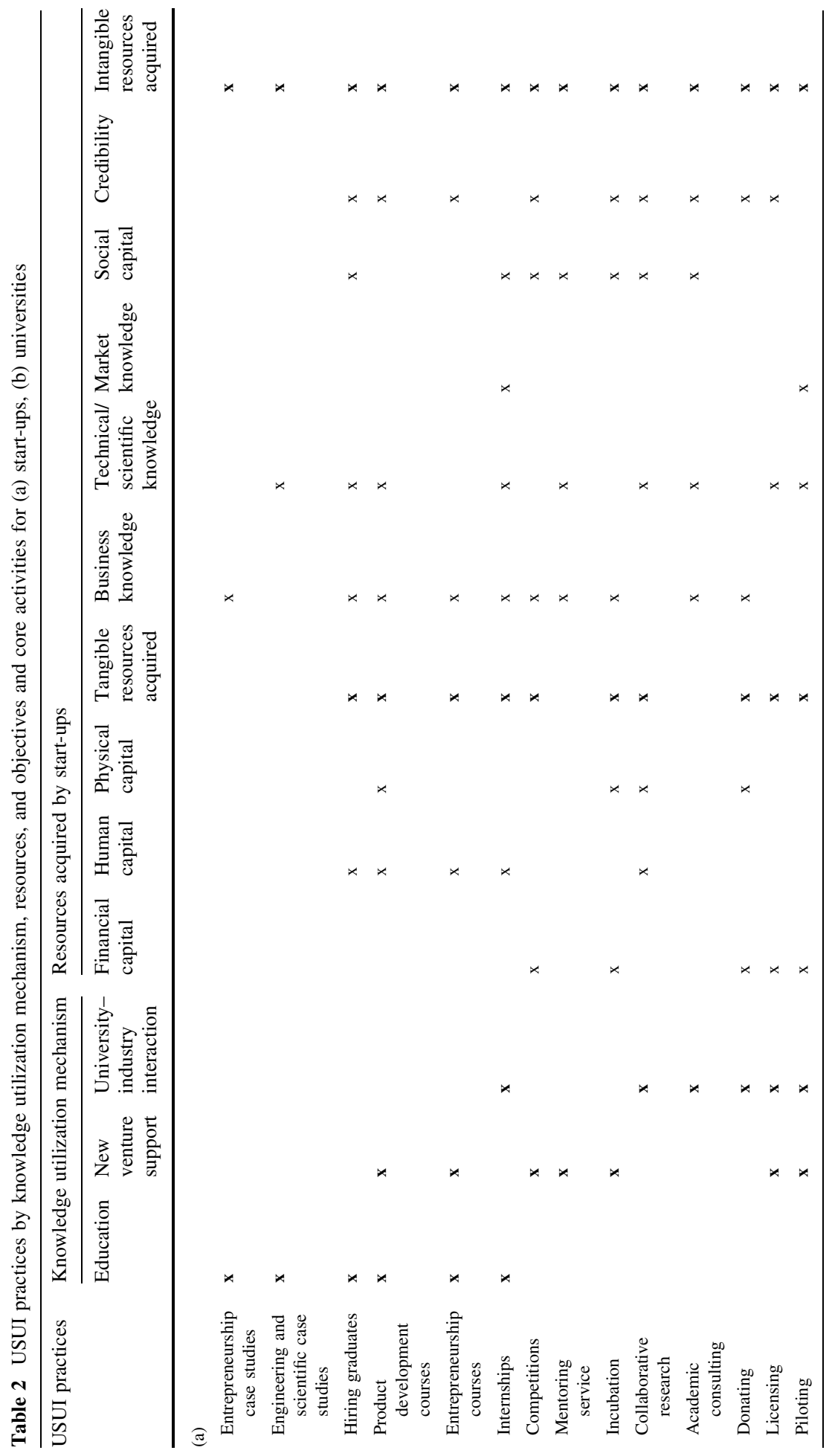




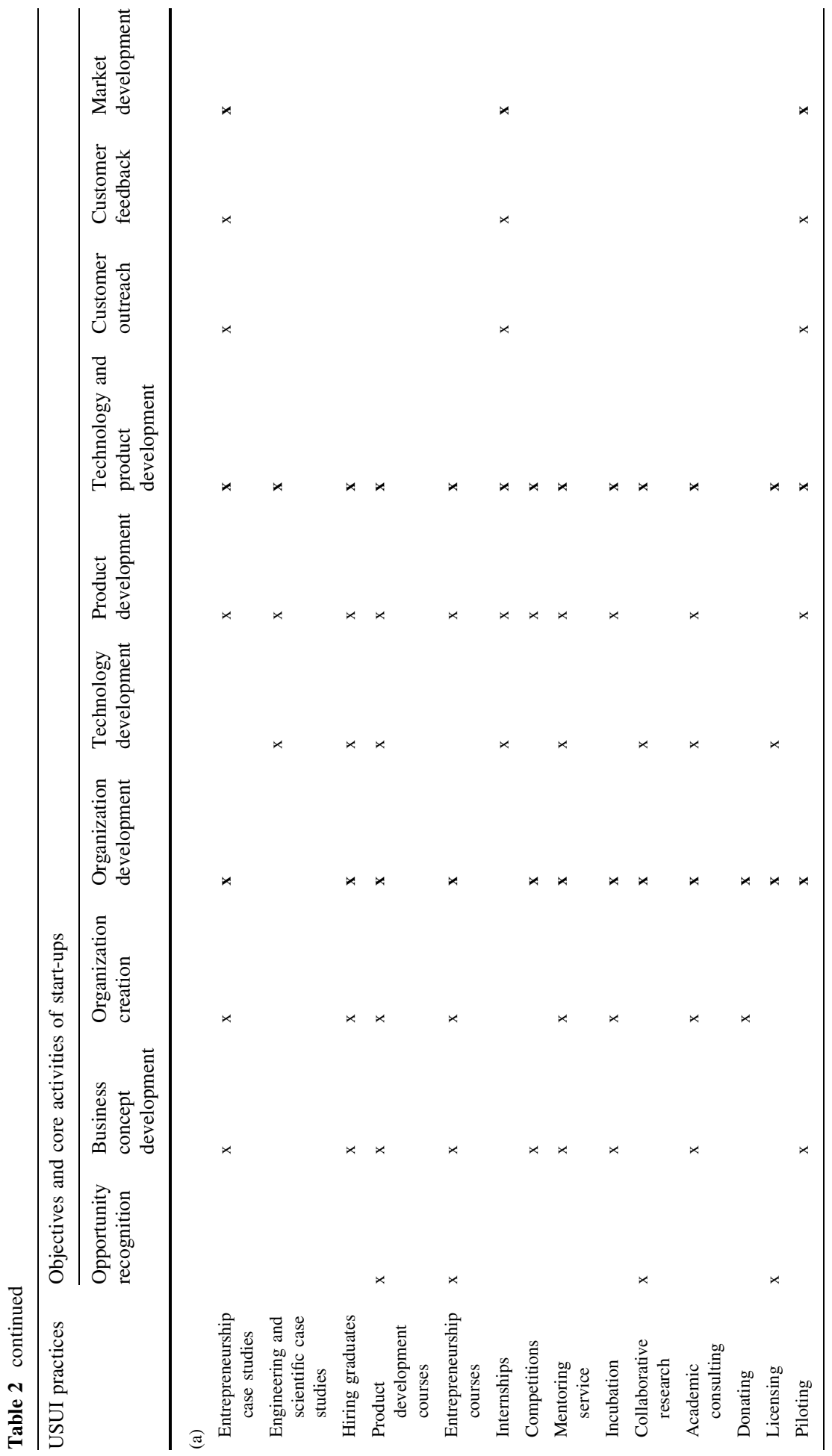




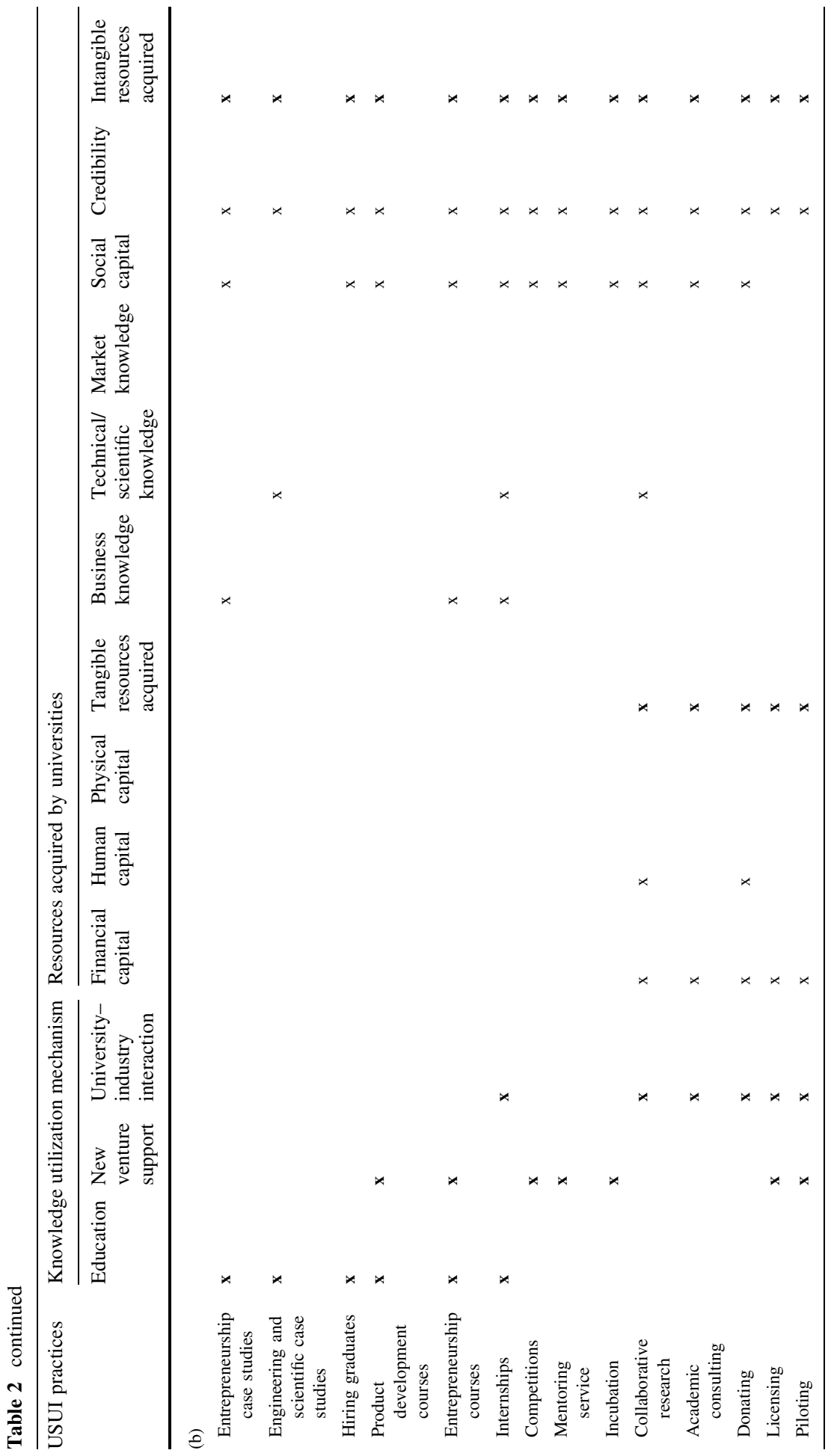




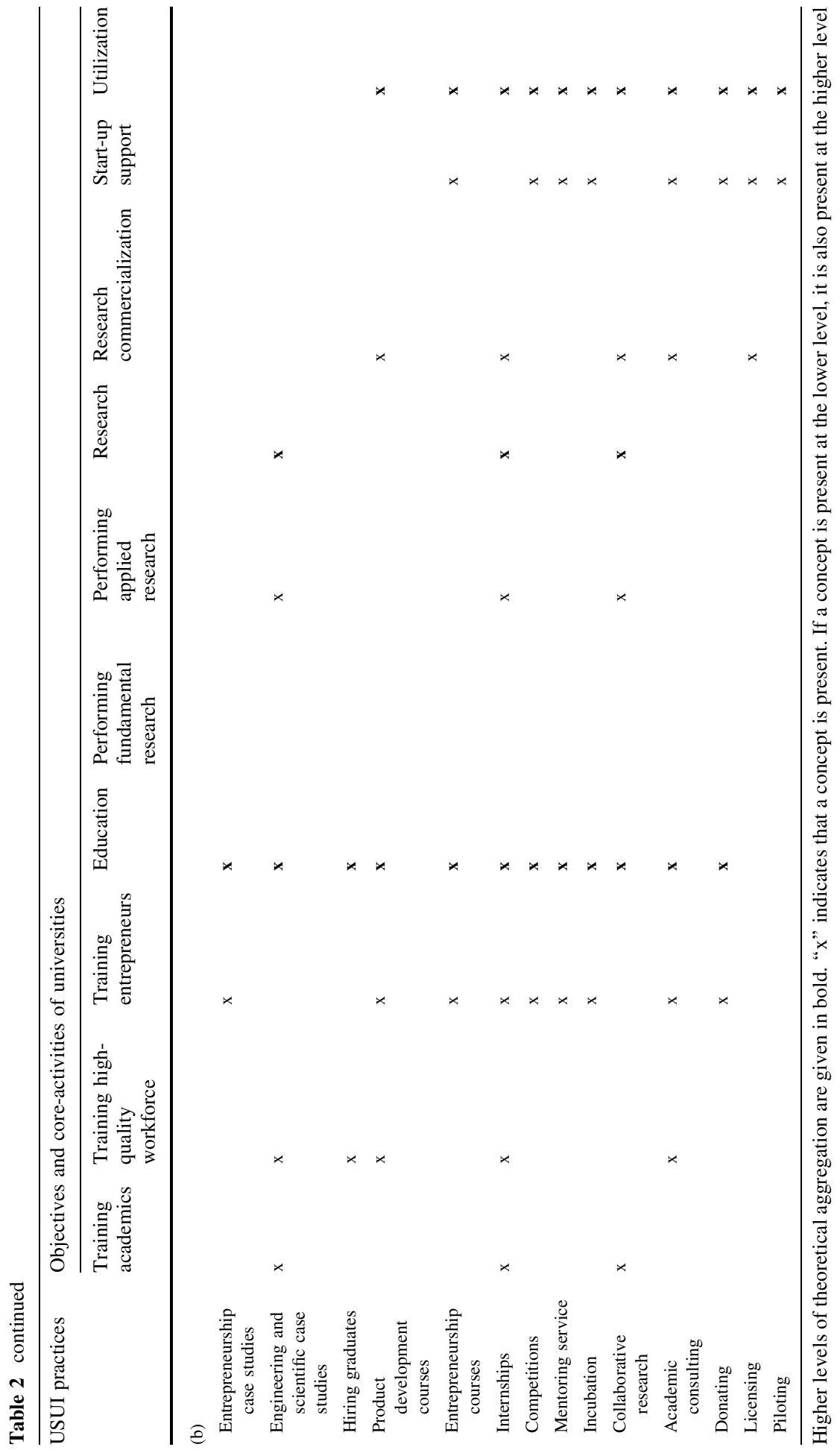


that a concept is associated with a practice. Higher categories of theoretical aggregation are given in bold; if a concept is present at the lower level, it is also present at the higher level.

Based on Table $2 \mathrm{a}$, we focus on the benefits that start-ups receive from USUI. For startups, all three utilization mechanisms offer both tangible and intangible resources. For education, the only tangible resource that is transferred is human capital, whereas new venture support provides financial and physical capital. UII practices involve all three types of tangible resources. For intangible resources, it is clear that universities can transfer these to start-ups through all USUI practices. This result can be explained by the fact that knowledge as key resource from universities is intangible and associated with all these USUI practices. The data also shows that start-ups are aware of that resources can be acquired through interaction with universities. As one entrepreneur put it; "It was pretty, you know, we tried to use the university for everything, you know, see it as a friendly, helpful resource for anything we could." (E1).

Also, entrepreneurs consider the university to be a relevant partner for both high-tech and low-tech start-ups; "If our venture was low tech, we sort of could have still used many of the MIT resources."... "But the high-tech venture has certain needs that fit with the resources of a university such as technical labs for example." (E1). This ability may be related to the variety of start-up objectives supported through USUI.

Organization development is supported by all practices except engineering and scientific case studies, and internships, both of which come from education. There is therefore a strong focus on organization development, although some practices contribute to this process through opportunity recognition, which is the very first stage of the organization development process. Universities also contribute strongly to technology and product development. All educational practices contribute to this objective and most other USUI practices do so as well; donating alone does not. However, when it comes to market development, only a few USUI practices contribute to this process. Even though market development is, according to some, the most important objective for a start-up (Ries 2011; Blank 2013), universities do not seem to have many ways of promoting this. This is most likely because market development is not part of the core competences of universities. A notable and creative way in which universities can contribute to this is piloting, which allows universities to be a test bed for some new products. "The biggest is feedback of the product. The next is, you know, like, product development, meaning we're able to test new features in the colleges and see how they react, and that's been very helpful" (E6). More indirectly, mentors can create awareness and give credibility, helping with market development.

The university also receives benefits from USUI (Table 2b). What is notable is that educational practices do not directly result in the return of any tangible resources, nor do practices that are solely based on supporting new ventures. However, these practices provide social capital to the universities, which in turn contributes to the practice of donating. This provides financial capital and human capital for universities. Here, the ecosystem characteristic of "paying it forward" is important as it is the main reason for donating to exist. Moreover, the diversity of support within the ecosystem allows universities to receive financial and human capital from a variety of industries. The only tangible resources that universities gain from USUI is through practices that come from the mechanism University-industry interaction. This can be explained by the fact that the startups often have limited tangible resources themselves. However, all practices do contribute to the intangible resource base of the university, primarily through credibility and building social capital. Both resources are important for gaining access to tangible resources such as government grants (Van Rijnsoever et al. 2014). In some instances, universities gain 
Box 1 Overview of USUI practices

\begin{tabular}{lll}
\hline USUI practice & Description & $\begin{array}{l}\text { Lit. } \\
(\mathrm{Y} / \mathrm{N})^{*}\end{array}$ \\
\hline
\end{tabular}

1. Entrepreneurship case studies

2. Engineering and scientific case studies

3. Hiring graduates

4. Product development courses

5. Entrepreneurship courses

6. Internships

7. Competitions

8. Mentoring services

9. Incubation

10. Collaborative research

11. Academic consulting

12. Donating

13. Licensing

14. Piloting
The invitation of entrepreneurs into the university classrooms to talk about and study real-life business problems, generating new knowledge on strategies in specific business situations

Education provided in collaboration between universities and start-up with a strong engineering focus, such as capstone projects or scientific projects with direct student (B.Sc./M.Sc.) involvement in industry. These projects aim to solve technical problems for start-ups, while the students involved earn course credits at the university

The hiring of (specialized) graduate students by start-ups

University taught courses with a strong engineering emphasis that aim to solve real-life problems and bring students from different disciplines together by building a functional and marketable product in class

University taught courses on developing a business through classes, often combined with action-based learning. This differs from the practice of Entrepreneurship case studies as the students in class take the active role of entrepreneur. Students receive course credits while working on a business plan

The participation of students in start-ups through an internship $\mathrm{Y}^{\mathrm{a}}$ construction

The participation of start-ups in business competitions organized $\mathrm{Y}^{\mathrm{b}}$ by universities

A service provided by universities, build around the long-term $\quad \mathrm{Y}^{\mathrm{b}}$ appointment of voluntary individuals (mostly experienced entrepreneurs or alumni; the mentors) to aid start-up development

The participation of start-ups in services provided by the university that aim to launch new start-ups

Research undertaken in collaboration between universities and $\mathrm{Y}^{\mathrm{a}}$ start-ups, including renting out laboratory space and specialized equipment, possibly against a fee

University staff providing direct advice or expertise to start-ups. $\quad \mathrm{Y}^{\mathrm{a}}$ This may also include the provision of networking opportunities

The act of giving resources away for free (performed by both $\quad \mathrm{Y}^{\mathrm{a}}$ universities and start-ups), as a sign of gratitude or encouragement

The protection and commercialization of intellectual property (IP) $\mathrm{Y}^{\mathrm{a}}$ that originated from academic research

The activities of universities which provide start-ups with a pilot $\mathrm{N}$ site or niche market for their product (usually the campus)

\footnotetext{
* Previously documented in the literature; Y (yes)/N (no)

${ }^{a}$ According to Ankrah and Omar (2015)

b According to Lackéus and Williams Middleton (2015)
} 
business knowledge from start-ups, but-surprisingly-no market knowledge is gained. The business knowledge can be used to enrich the teaching curriculum; “...it's I think a real hard interaction that says, the world of business takes place outside the university. How we bring that world inside the university, so you can study it and so you can learn from it." (U2). As such, the educational objectives benefit from all USUI practices except from licensing and piloting. However, it should be noted that it is mostly entrepreneurship education that benefits.

Research, on the other hand, has little association with USUI practices. There are examples of research benefiting from education and UII, but not from new venture support. Moreover, only applied research is strengthened. If the objective of the university is indeed solely to strengthen its scientific credibility (Latour and Woolgar 1979), interacting with start-ups seems to offer limited potential. Finally, USUI practices do directly contribute to the knowledge utilization objective, especially all practices from new venture support and UII. Education in this context does not always contribute to knowledge utilization, but the knowledge the graduates receive during education can later be applied in society. As such, knowledge utilization through education is also an indirect process.

\section{Conclusions}

This study aimed to explores the conditions under which the USUI process is mutually beneficial to both universities and start-ups in terms of resources. To this end, we identified 14 USUI practices, we categorized the resources that are transferred through these practices, and we looked at how these practices contribute to the objectives of both start-ups and universities. It is evident from the results that the USUI concept is different from conventional university-industry interaction (Perkmann et al. 2013), because start-ups need different resources than large firms (Ries 2011), and because USUI concept also includes education and new venture support as the transfer mechanisms. We summarize the conclusions and their implications as follows:

First, we find that USUI is largely based on intangible resources. These are often important for gaining competitive advantage as they are more likely to be rare and inimitable (Amit and Schoemaker 1993). However, their presence-and thus their added value - is hard to quantify, which makes it difficult to see the use of USUI practices. This is especially problematic for start-ups, as their key performance indicators are often based on tangible resources like the amount of capital raised or the number of users (Greene et al. 2015). Within an ecosystem with a culture of "paying it forward" (Ready 2012) and high diversity, universities do transfer crucial tangible resources to start-ups in the hope that the favor will be returned in the future when the start-up has matured, for example in the form of contributions to educational programs or even financial donations. However, indicators need to be developed that also incorporate of the added value of the intangible resources that come from each of the practices. This is an avenue for further research.

Second, the resources that the university transfers to start-ups mostly relate to organization and product development, but little to market development. This is a crucial gap as new market development is key for the success of academic start-ups (Soetanto and Jack 2016). If universities wish to strengthen their venture support activities, strengthening market development is crucial. Universities are taking up this challenge by incorporating market development in their programs, for example by following the lean start-up method (Ries 2011; Blank 2013). Furthermore, using the university as pilot site for new ventures is 
one interesting avenue. However, start-ups with a product that does not benefit from the technical or scientific knowledge or credibility of universities should carefully consider the added value of being involved in start-up support programs originating from a university. Support programs that originate from corporations or independent programs might better fit their needs. Using our results, future research needs to look at the decision of start-ups to engage in USUI practices in comparison to other start-up support mechanisms or working with other actor types.

Third, universities can for the most part strengthen their educational programs through USUI, specifically those related to entrepreneurship. Also, the knowledge utilization objective benefits from USUI. This means that USUI practices largely provide resources that reinforce themselves. However, there are no clear links to fundamental research, which many universities value as their core activity and which is the source of much scientific credibility (Latour and Woolgar 1979). Universities with a strong focus on fundamental research thus have less incentive to engage in USUI practices than those that focus more on application. The lack of a strong connection between fundamental research and USUI practices is not a direct problem as USUI partly reinforces itself and caters to the demand of students with a more practical orientation. However, if the aim of USUI practices is also to strengthen fundamental research activities, practices should be designed to bring the world of starting new ventures and fundamental research closer together. Policy makers can catalyze this process by providing incentives for universities to develop fundamental knowledge in collaboration with start-ups. An example of this is the SBIR scheme in the US (www.sbir.gov). Future researchers need to focus attention on the conditions under which researchers from universities are likely to engage in USUI practices. The list of resources and objectives provided here can serve as input for such a study.

This leads us to draw the overall conclusion that whether USUI is beneficial or not largely depends on how organizations value their different objectives. Science-based startups are more likely to benefit from USUI, whereas start-ups close to market might be better off with other support programs. Universities with a strong focus on fundamental 'Mode 1' research benefit less from USUI than those that are more engaged in applied 'Mode 2' research, or have a strong focus on teaching and knowledge utilization. Theoretically, we add to the existing literature about the interaction between entrepreneurs and universities by explicitly studying incentives for the USUI process from the perspective of both actor types. We show that USUI can reinforce and sustain the entrepreneurial orientation (Etzkowitz 2004) of universities, and can be beneficial to science-based start-ups. However, our results also imply that universities that do not follow the societal trend to more societal relevant and applied research (Hessels and van Lente 2008) have little to gain from USUI. These 'Mode 1' universities are also in a poor position to aid science based start-ups with their market development, which is important for survival of these start-ups (Soetanto and Jack 2016).

\section{Limitations}

There are a number of limitations in this research that should be taken into account. The theory and data analysis resulted in a clear overview of the exchange of resources, and of the potential benefits universities and start-ups can create through collaboration. However, the framework does not acknowledge the conditions for successful interactions and the implementation requirements to benefit from the resources. These conditions can partly be 
created in university incubators and on science parks (Ratinho and Henriques 2010). However, the institutional conditions of the entrepreneurial or innovation ecosystem also determine the extent to which USUI becomes a success (Stam 2015; Van Weele et al. n.d.). We have now studied start-ups in the clean-tech industry in Boston, which has a specific 'pay it forward' culture, a high diversity and a favorable regime towards clean-tech. The interaction between universities and start-ups with a different industry orientation (such as information technology or life sciences) or from a different region, might reveal additional resource exchange patterns. Yet, we do note that if even in this relatively successful region, start-ups and universities do not fully strengthen their core goals, this is less likely to happen in other regions. Future research needs to focus on the interactions between universities and other types of start-ups in other regions. Another limitation is that universities are heterogeneous in their orientation toward the knowledge utilization objective (D'Este and Patel 2007; Perkmann et al. 2013), and their capabilities to do so (Rasmussen and Wright 2015). According to Göransson (2009), a country's history influences the role of universities beyond teaching and research. Respectively, the objectives will vary strongly based on the location of universities (Göransson 2009) and will affect the pattern of USUI. Moreover, we noticed that characteristics of the ecosystem influence the viability of USUI, as we have seen with the characteristics "paying it forward" and diversity. Therefore, the findings of the study should be placed in context when deriving theoretical and practical implications.

Open Access This article is distributed under the terms of the Creative Commons Attribution 4.0 International License (http://creativecommons.org/licenses/by/4.0/), which permits unrestricted use, distribution, and reproduction in any medium, provided you give appropriate credit to the original author(s) and the source, provide a link to the Creative Commons license, and indicate if changes were made.

\section{Appendix 1: Characteristics of sample respondents}

\begin{tabular}{lll}
\hline Type of organization & Further specification & Position of respondent \\
\hline Accelerators (3) & & Executive Director \\
Accelerator & & Program Manager \\
Accelerator & & \\
Accelerator & & CEO \\
Incubators (2) & & Director \\
Incubator & & \\
Incubator & & Associate \\
Investors (3) & Investor \\
Investor & Founder and CEO \\
Investor & Industry & Founder and CEO \\
Investor & Recycling & Founder and CEO \\
Start-ups (13) & Agriculture & Founder and CEO \\
Startup & Agriculture & Founder and CEO \\
Startup & Building management & \\
Startup & & \\
Startup & &
\end{tabular}




\begin{tabular}{|c|c|c|}
\hline Type of organization & Further specification & Position of respondent \\
\hline Startup & Food and water & Founder and CEO \\
\hline Startup & Food and water & Employee \\
\hline Startup & Oil and gas & Founder \\
\hline Startup & Oil and gas & Employee \\
\hline Startup & Solar energy & Founder and CEO \\
\hline Startup & Urban transportation & Founder and CEO \\
\hline Startup & Wind energy & Founder \\
\hline Startup & Wind energy & Employee \\
\hline Startup & Wind energy & Employee \\
\hline Universities (9) & Department & \\
\hline University & Faculty & $\begin{array}{l}\text { Program and Admission } \\
\text { Assistant }\end{array}$ \\
\hline University & Univ. Incubator & Assistant Director \\
\hline University & Faculty & Senator \\
\hline University & Faculty & Assistant Professor \\
\hline University & Faculty & Assistant Professor \\
\hline University & Univ. Accelerator & Director \\
\hline University & $\begin{array}{l}\text { Univ. Entrepreneurship mentor } \\
\text { Service }\end{array}$ & Senior Venture Analyst \\
\hline University & Univ. Entrepreneurship center & Executive Director \\
\hline University & Univ. TTO & Director \\
\hline \multicolumn{3}{|l|}{ Other (6) } \\
\hline Industry council & & Director \\
\hline Makerspace & & Founder \\
\hline Media & & Associate Editor \\
\hline Regional TTO & & Director \\
\hline $\begin{array}{l}\text { Entrepreneurship education } \\
\text { program }\end{array}$ & & Founder and CEO \\
\hline Collaborative workspace & & Development Leader \\
\hline
\end{tabular}




\section{Appendix 2: Interview scripts}

\section{Operationalization table}

\begin{tabular}{llll}
\hline Interview script*: & Entrepreneurs & University repr. & Third party repr. \\
\hline Actor objectives (both univ./start-ups) & $7,8,10$ & 6 & 5,6 \\
\hline Resources & $7 a, b$ & $6 b$ & $5 a, 6 a$ \\
\hline Description of interaction practices & $6 b, 9$ & 3,4 & 3,4 \\
\hline Conditions for USUI & $11,12,13,14$ & 7 & $7,8,9$ \\
\hline Ecosystem characteristics & $15,16,17$ & $8,9,10$ & $10,11,12$ \\
\hline
\end{tabular}

${ }^{*}$ Numbers in each column refer to the number of the question(s) in each script that operationalize the key concepts.

\section{Interview script 1: For Entrepreneurs}

\section{Part 1: Introduction}

1. Could you briefly describe your personal background? (e.g. entrepreneurial experience, education)
a. What was your occupation prior to this start-up?
b. What were your motivations to become an entrepreneur?
c. [If former student/PhD/professor/researcher] Is the start-up based on (academic or non-academic) research results?

\section{Part 2: start-up}

2. Could you give a brief background of the start-up (e.g. product, birth, current number of employees)?
a. In what sector/industry does the start-up operate?
b. How would you describe the phase of development your firm is currently in (e.g. product development, market orientation, sustainable returns)?

3. Are you familiar with the Lean Startup Method? [if YES: Q.4 if NO: Q.8]

4. Did you create a minimum viable product (MVP)?
a. Could you explain how the MVP was created?
b. Why did you create a MVP (e.g. building a proof of concept) ?
c. Did you have to pivot from your original product?

5. Did the firm need external investment?

a. Under which conditions are these investments made?

\section{Part 3: University-start-up Interaction (USUI)}

6. If any, what connections does your firm have with the university? 
a. What type of university representatives do you interact with (e.g. faculty professor, TTO manager, students)?

b. What type of interaction method is used in cooperation with the university (e.g. education, mentoring, contract research)?

i. Would you classify this interaction method formal or informal?

ii. How often do you interact [specify what is meant by interactions, based on explanation of method used: e.g. \# of interns, weekly meetings with professor etc.]?

7. Why does the start-up interact with the university?

a. What type of knowledge/resource is acquired by means of interaction (e.g. technical knowledge/lab space)?

b. Are there any other resources/knowledge acquired through other forms of interaction with universities that have not yet been mentioned?

[For the different interactions:]

8. In what way does this interaction contribute to firm development (e.g. student internships)?

a. What are the results of the support, based on a view of the firm (e.g. faster prototyping because of increased work force)?

b. What is the effect of these results in terms of firm development (e.g. quick time to market because of faster prototyping)?

9. How was this cooperation established (e.g. through incubator, TTO's, networking events)?

a. Why did your firm turn to the university (in comparison to other org's)?

10. What are, according to you, the reasons for universities to interact with you [here a quick indication is enough]?

As we have discussed in what way the university supports your firm development, I now would like to focus on barriers and opportunities for USUI.

11. Does your firm experience any difficulties with USUI?

a. If yes, then how?

12. Is there any kind of support offered by the universities in the Boston area that you do not make use of?

a. If yes, then why? 
13. Do the universities play a pro-active role, or do you mostly initiate the support process?

14. If so, at what point in your business' development cycle do you expect that U-I interaction will become a disadvantage. And if so, then why?

\section{Part 4: Innovation System/context}

15. What do you consider to be weak and strong points of the entrepreneurial ecosystem your start-up operates in?

a. How would you describe the:
i. Capital market
ii. Entrepreneurial community
iii. Overall culture (e.g. risk taking, ambition, status of entrepreneurs)
iv. Regulations

16. Which actors in the ecosystem do you consider to be very important? Which actors are missing (e.g. investors, incubators, active government, etc.).

17. Do you have any suggestions to increase the emergence and growth of start-ups in your industry?

\section{Interview script 2: For University Representatives}

\section{Interview questions:}

\section{Part 1: Introduction}

1. Could you briefly describe your personal background? (e.g. position, education, entrepreneurial experience)

a. What are your responsibilities within this department?

b. What was your occupation prior to this function?

c. [If former entrepreneur] Are your current activities based on your former entrepreneurial activities?

\section{Part 2: Program/department background}

2. Could you briefly describe the program/department background in which you are currently active (E.g. when was it founded, what's its purpose, size in terms of employees, the annual budget)?

a. What is the orientation of the university (Liberal Arts/Institute of Technology)?

We now have discussed your personal \& organizational background. I would like to ask you several questions on the interaction between your university and start-ups.

\section{Part 3: University-start-up interaction (USUI)}


3. What are the interaction links between your department/faculty/program and start-ups (e.g. collaboration, internships, mentoring, founder)?

4. What start-ups do you interact with (high-tech/low-tech)?

5. What are types of interaction methods used in cooperation with start-ups?

a. What type of start-up representative does the university interact with (e.g. founders, engineers, researchers)?

b. How does your program/department connect with these start-ups?

i. Who is taking the initiative in this relationship?

6. Why does your department/faculty/program interact with start-ups?

a. How do these interactions contribute to university activities (e.g. education, research, entrepreneurial support)?

b. What type of knowledge/resource is acquired by means of interaction (e.g. technical knowledge)?

c. Would you classify this interaction method formal or informal?

d. How often do the parties interact with each other [specify what is meant by interactions, based on explanation of method used: e.g. \# of interns, weekly meetings with professor etc.]?

As we have discussed in what way start-ups can support universities, I now would like to focus on future opportunities for U-I interaction.

7. Do you experience any difficulties interacting with startups?

a. If yes, why?

\section{Part 4: Innovation System/context}

8. What do you consider to be weak and strong points of the entrepreneurial ecosystem your start-up operates in?

a. How would you describe the:
i. Capital market
ii. Entrepreneurial community
iii. Overall culture (e.g. risk taking, ambition, status of entrepreneurs)
iv. Regulations

9. Which actors in the ecosystem do you consider to be very important? Which actors are missing (e.g. investors, incubators, active government, etc.). 
10. Do you have any suggestions to increase the emergence and growth of start-ups in your industry?

\section{Interview script 3: For Third Party Representatives}

\section{Interview questions:}

\section{Part 1: Introduction}

1. Could you briefly describe your personal background? (e.g. position, education, entrepreneurial experience)

a. What was your occupation prior to this function?

b. [If former entrepreneur] Are your current activities based on your former entrepreneurial activities?

2. Could you briefly describe the program/organization you are working with (E.g. when was it founded, with what purpose, annual budget, size in terms of employees and start-ups)?

We now have discussed your personal \& organizational background. I would like to ask you several questions on the ways universities and start-ups interact. Please answer these questions for your field of expertise (e.g. Clean-tech/High-tech/IT/Life Sciences).

\section{Part 2: University-start-up interaction (USUI)}

3. What interactions between universities and start-ups do you know of?

4. What are the types of interaction methods used in cooperation between universities and start-ups?

a. How is this cooperation established (e.g. through incubator, TTO's, networking events)?

i. What type of representatives interact (e.g. founders, engineers, teachers, researchers, TTO managers)?

ii. Who is taking the initiative in this relationship?

5. Why do start-ups interact with universities?

a. What resources are being transferred to start-ups through USUI?

b. How do these interactions contribute to start-up activities (e.g. idea generation, business concept development, founding a physical organization, developing production technology etc.)?

6. Why do universities interact with start-ups? 
a. What resources are being transferred to universities through USUI?

b. How do these interactions contribute to university activities (e.g. education, research, entrepreneurial support)?

\section{Part 3: Conditions for USUI}

7. Are there barriers for USUI (e.g. cases that have not worked out or are difficult)?

a. If yes, then why?

8. Are there opportunities for USUI (e.g. successful cases)?

a. If yes, then why?

9. Do you expect that USUI will become a disadvantage on the long term? And if so, then why?

\section{Part 4: Innovation System/context}

10. What do you consider to be weak and strong points of the entrepreneurial ecosystem your start-up operates in?

a. How would you describe the:

i. Capital market

ii. Entrepreneurial community

iii. Overall culture (e.g. risk taking, ambition, status of entrepreneurs)

iv. Regulations

11. Which actors in the ecosystem do you consider to be very important? Which actors are missing (e.g. investors, incubators, active government, etc.).

12. Do you have any suggestions to increase the emergence and growth of start-ups in your industry?

\section{Appendix 3: Full description of USUI practices}

In total, we identified 14 USUI practices from our data. A full description of each practice is provided for below.

1. Entrepreneurship case studies comprises the invitation of entrepreneurs into the university classrooms to talk about and study real-life business problems, generating new knowledge on strategies in specific business situations. Hereby, new knowledge on strategies in specific business situations is generated. Start-ups benefit from this as entrepreneurship case studies allow for a "community of practice" (Wenger 1998) to develop, in which start-ups acquire business knowledge in support of business concept development, organization creation, product development, customer outreach, and customer feedback. Universities, on the other hand, also receive business knowledge as start-ups offer state-of-the-art empirical data. The knowledge generated is used directly to shape entrepreneurship 
education. Therefore, the subject material is considered to be "shaped at the frontier" and adds to the universities' credibility in training entrepreneurs. Moreover, universities acquire social capital through entrepreneurship case studies as this "service" to entrepreneurs nourishes alumni networks.

2. Engineering and scientific case studies entails forms of education provided in collaboration between universities and start-up with a strong engineering focus, such as capstone projects or scientific projects with direct student (B.Sc./M.Sc.) involvement in industry. These projects aim to solve technical problems for startups, while the students involved earn course credits at the university. Start-ups acquire technical or scientific knowledge as students work on technology- or product-related problems, contributing to the technological development and product development of the firm. In return, university staff and students acquire technical or scientific knowledge while working with state-of-the art technologies. Moreover, they gain insights into "the business side of things" (Professor) due to the start-up's commercial orientation. As such, the practice adds to training academics, training a high-quality workforce, and performing applied research. Moreover, being "involved" with state-of-the-art technologies yields credibility in performing collaborative research with high-tech industry, which favors undertaking applied research.

3. Hiring graduates refers to the hiring of (specialized) graduate students by start-ups and is one of the most frequently used USUI practices by start-ups. Start-ups receive human capital by hiring graduates, who may carry business knowledge, technical or scientific knowledge, direct links with the university (social capital), and a university degree that grants the firm credibility. Start-ups allocate business knowledge to business concept development and organization creation, whereas technical or scientific knowledge and networks support technology development and product development. Credibility is used as an asset in fundraising, which favors all core activities. Meanwhile, universities acquire social capital as their network expands by including new start-ups. Moreover, universities earn credibility as they deliver appropriate education, which is an argument used to attract new students and evidence that they train a high-quality workforce.

4. Product development courses are university taught courses with a strong engineering emphasis that aim to solve real-life problems and bring students from different disciplines together by building a functional and marketable product in class. Some of these project groups start new companies based on their work in class. Therefore, this practice facilitates opportunity recognition. Second, the project group is an initial human capital base for the start-up to draw from. During the course, the (pre)start-up is offered workspace and tools (physical capital), business knowledge, and technical or scientific knowledge by professors and experienced entrepreneurs. This adds to business concept development and organization creation. Moreover, the technical or scientific knowledge acquired is helpful in technology development and product development in the start-up. Finally, originating from a university gives the start-up credibility with stakeholders such as investors. Again, universities can expand their network (social capital) with new entrepreneurs and gain credibility from a successful startup. Overall, they strengthen their core activities to train a high-quality workforce and entrepreneurs.

5. Entrepreneurship courses entails university taught courses on developing a business through classes, often combined with action-based learning. This differs 
from the practice of Entrepreneurship case studies as the students in class take the active role of entrepreneur. In doing so, students receive course credits while working on a business plan, allowing them to concentrate on both their education and founding a company. Therefore, this practice entails both education and new firm mechanisms. In some cases, start-ups are formed during entrepreneurship courses, and benefit directly from the availability of human capital and business knowledge present in the classroom. Moreover, credibility is earned through the affiliation with the university. These resources contribute to opportunity recognition, business concept development, organization creation, and product development. Universities benefit as the constant application of entrepreneurship theories in practice creates opportunities to study best practices at their core and generate business knowledge. Furthermore, universities increase their social capital and gain credibility. The practice reinforces universities in training entrepreneurs and start-up support.

6. Internships concerns the participation of students in start-ups through an internship construction. Internships enable start-ups to hire high quality human capital against relatively low costs. Interns fulfill roles in both entrepreneurial and engineering assignments, depending on their training at the university. As such, the core activities of technology development, product development, customer outreach, and customer feedback are supported. Through internships, universities that supervise the students interact with the start-up, and acquire tacit technical or scientific knowledge and business knowledge, as well as network contacts. This increases their students' value on the labor market. Second, it enables future academics to make a better contribution to the activity of undertaking applied research. Finally, internships at start-ups provide credibility to the university as it demonstrates that their graduates do relevant work. Therefore, internships add to the training of academic professionals, a high-quality workforce, and entrepreneurs, as well as engagement in applied research and research commercialization.

7. Competitions refer to the participation of start-ups in business competitions organized by universities. With competitions, universities allocate mentors to the competing start-ups that coach the teams. These mentors often have experience in business and are therefore considered a valuable resource for transferring business knowledge. This is an important aid to start-ups in business concept development and product development. Furthermore, working with mentors may give access to a network, which has been shown to be helpful for later fundraising and speeding up product development. Finally, competitions elect winners and finalists that are compensated financially and announced publicly. This gives start-ups financial capital and credibility that aids with raising more funds. Through competitions, universities gain social capital and credibility as they connect with start-up teams that reflect the technological and entrepreneurial abilities of the university. Consequently, students are encouraged to start their own business or take entrepreneurship classes, creating a support base for training entrepreneurs and start-up support.

8. Mentoring services are a kind of service provided by universities, build around the long-term appointment of voluntary individuals (mostly experienced entrepreneurs or alumni; the mentors) to aid start-up development. Start-ups benefit from the professional experience of the mentors and their professional networks as they have access to technical or scientific knowledge, business knowledge, and social capital. Mentoring time is mainly spent on coaching for business concept 
development and organization creation. To a lesser extent, mentors help to solve technical problems and contribute to technology development and product development. Finally, the mentors' networks indirectly provide access to expert knowledge or introductions to first customers. Universities engage in this practice because of the social capital gained through working with both the start-ups and the mentors. Furthermore, the establishment of a successful mentoring service can draw attention and be a source of credibility with nascent entrepreneurs. Both can attract mentoring volunteers, reinforcing the activities of training entrepreneurs and start-up support.

9. Incubation covers the participation of start-ups in services provided by the university that aim to launch new start-ups. First, through the university incubator, start-ups have a place to work (physical capital), which contributes to the creation of the physical organization. Second, most universities have funding available for their incumbents, providing start-ups with the financial capital required to produce prototypes, and thus aiding product development. Third, incubated start-ups may enroll for classes and incubator staff may also provide business knowledge. The staff may also connect the start-ups with important contacts, expanding the startups' social capital. Finally, the relationship with the university gives the start-ups credibility, which may be helpful in later fundraising. In terms of benefits, universities gain social capital and credibility from the incubated start-ups. Facilitating entrepreneurship teams brings together students from different schools, benefiting the social cohesion within universities. Second, universities gain credibility for their abilities to promote entrepreneurship, which attracts new (entrepreneurship) students. This complements the universities' entrepreneurship education and creates a basis for start-up support.

10. Collaborative research refers to research undertaken in collaboration between universities and start-ups, including renting out laboratory space and specialized equipment, possibly against a fee. Collaborative research provides start-ups with university-owned laboratory space and specialized equipment, a type of physical capital is scarce for them. Furthermore, start-ups acquire technical or scientific knowledge through collaborative research. University researchers can also join firms for a longer period of time, as an employee, to carry out research. This allows for more hands-on transferal of university knowledge and adds to human capital. These resources may benefit the technological development of start-ups, or may clarify whether a technology has real commercial value (opportunity recognition). Moreover, collaborative research is a source of credibility as the expertise of the university is reflected in the start-up. For universities, collaborative research is a means of acquiring financial capital through research funding or renting out physical capital. In addition, collaborative research allows universities to acquire technical or scientific knowledge. Moreover, the collaboration expresses researchers' expertise in a specific discipline and thus provides credibility, which helps attract additional funds. This practice strengthens the implementation of applied research and contributes to research commercialization.

11. Academic consulting consists of university staff providing direct advice or expertise to start-ups. This may also include the provision of networking opportunities. As such, academic consulting allows universities to train students outside the curriculum in a highly goal-oriented manner. The university staff members thus constitute an external source for business, technical or scientific knowledge, and to some extent social capital and credibility. These resources can 
be used to improve business concept development, organization creation, technology development and product development. Consulting may be free for start-ups if it is considered a small service on the part of the staff. If consulting requires more time, the university may ask for financial compensation. In addition, academic consulting contributes to social capital and the credibility of academics. Overall, academic consulting contributes to training a high-quality workforce, training entrepreneurs, and research commercialization.

12. Donating is the act of giving resources away for free (performed by both universities and start-ups), as a sign of gratitude or encouragement. In this way, universities supply start-ups with financial capital and physical capital, such as providing a small fund to enable further development of a technology (technology development) or old furniture for an office space (organization creation). Donation is an important USUI practice in the culture of "paying it forward"; there is reason for providing an act in return. The entrepreneurs supported by the university often want to return the favor. Based on this practice, universities acquire financial capital and other offers from experienced and successful entrepreneurs, such as volunteer work as a mentor (human capital). Donations are also a source for credibility for the university in supporting entrepreneurship. These donated resources are mostly employed to support start-ups through other USUI practices, such as incubation, mentoring services, and competitions. Therefore, donation strengthens the training of entrepreneurs and start-up support.

13. Licensing is a USUI practice that serves the protection and commercialization of intellectual property (IP) that originated from academic research. Licensing contributes to opportunity recognition in start-ups as the knowledge it protects forms the basis for starting a business. Moreover, when licensing a technology, it is not uncommon for universities to supply the founding researchers with funding (financial capital) for spin-off and to develop the licensed technology further for commercialization (technology development). Finally, patents are seen as a source of credibility to start-ups as they are a mark of the originality of a technology. As licensing IP is costly, the universities see gap funding as an investment. Most universities own the IP and receive some sort of financial reimbursement (financial capital) when start-ups generate profit, which universities can allocate to entrepreneurship education and start-up support: "We set aside 30\% of any revenues that flow back to the inventor pool" (Professor). Moreover, having licensed successful companies provides universities with credibility for their ability to commercialize knowledge.

14. Piloting refers to the activities of universities which provide start-ups with a pilot site or niche market for their product (usually the campus). Start-ups acquire financial capital through piloting as the university becomes the first customer of their technology. This allows the start-up to test its product's behavior and durability in real life, and to interact with lead consumers (students and staff), providing technical or scientific knowledge and market knowledge. Moreover, start-ups can test their business model. Through multiple iterations, piloting contributes to business concept development, customer outreach, and customer feedback. Furthermore, having a university as a customer increases the credibility of the start-up and may be used as an argument in fund raising. With these new technologies on campus, universities may also gain financial capital by contract. Moreover, the visibility of being a test bed for innovations provides credibility, which will generate support for start-up support. Given that we studied clean-tech 
start-ups, we also found that campus sustainability offices value the new technologies in terms of establishing a "green" campus culture.

\section{References}

Adams, J. D., Chiang, E. P., \& Starkey, K. (2001). Industry-university cooperative research centers. The Journal of Technology Transfer, 26(1-2), 73-86.

Adler, P. S., \& Kwon, S.-W. (2002). Social capital: Prospects for a new concept. The Academy of Management Review, 27(1), 17-40. Retrieved from http://www.jstor.org/stable/4134367.

Albert, P., \& Gaynor, L. (2000). Incubators-growing up, moving out: A review of the literature. ARPENT: Annual Review of Progress in Entrepreneurship, 1, 158.

Almeida, P., \& Kogut, B. (1997). The exploration of technological diversity and geographic localization in innovation: start-up firms in the semiconductor industry. Small Business Economics, 9(1), 21-31.

Amit, R., \& Schoemaker, P. P. J. H. (1993). Strategic assets and organizational rent. Strategic Management Journal, 14(1), 33-46.

Ankrah, S., \& Omar, A.-T. (2015). Universities-industry collaboration: A systematic review. Scandinavian Journal of Management, 31(3), 387-408.

Ardichvili, A., Cardozo, R., \& Ray, S. (2003). A theory of entrepreneurial opportunity identification and development. Journal of Business Venturing, 18(1), 105-123.

Åstebro, T., Bazzazian, N., \& Braguinsky, S. (2012). Startups by recent university graduates and their faculty: Implications for university entrepreneurship policy. Research Policy, 41(4), 663-677.

Audretsch, D. B. (1995). Innovation, growth and survival. International Journal of Industrial Organization, 13(4), 441-457.

Audretsch, D. B. (2007). The Entrepreneurial Society. Oxford: Oxford University Press.

Audretsch, D. B., Hülsbeck, M., \& Lehmann, E. E. (2012). Regional competitiveness, university spillovers, and entrepreneurial activity. Small Business Economics, 39(3), 587-601.

Audretsch, D. B., \& Lehmann, E. E. (2005). Does the knowledge spillover theory of entrepreneurship hold for regions? Research Policy, 34(8), 1191-1202. doi:10.1016/j.respol.2005.03.012.

Austin, A. (2002). Preparing the next generation of faculty: Graduate school as socialization to the academic career. The Journal of Higher Education, 73(1), 94-122.

Baber, Z., Gibbons, M., Limoges, C., Nowotny, H., Schwartzman, S., Scott, P., et al. (1994). The new production of knowledge: The Dynamics of Science and Research in contemporary societies. Contemporary Sociology (Vol. 24). London: Sage. doi:10.2307/2076669.

Barney, J. B. (1991). Firm Resources and Sustained Competitive Advantage. Journal of Management, 17(1), 99-120.

Barney, J. B. (1997). Gaining and sustaining competitive advantage. Reading, Massachusetts: AddisonWesley Pub. Co.

Becker, M. C. (2004). Organizational routines: A review of the literature. Industrial and Corporate Change, 13(4), 643-677.

Bellucci, A., \& Pennacchio, L. (2015). University knowledge and firm innovation: Evidence from European countries. The Journal of Technology Transfer. doi:10.1007/s10961-015-9408-9.

Bhave, M. P. (1994). A process model of entrepreneurial venture creation. Journal of Business Venturing, 9(3), 223-242.

Blank, S. (2013). Why the Lean Start-Up Changes Everything. Harvard Business Review, 91(5), 63-72.

Boh, W., De-Haan, U., \& Strom, R. (2015). University technology transfer through entrepreneurship: Faculty and students in spinoffs. The Journal of Technology Transfer. doi:10.1007/s10961-015-9399-6.

Bozeman, B., Fay, D., \& Slade, C. P. (2013). Research collaboration in universities and academic entrepreneurship: the-state-of-the-art. The Journal of Technology Transfer, 38(1), 1-67. doi:10.1007/ s10961-012-9281-8.

Bramwell, A., \& Wolfe, D. A. (2008). Universities and regional economic development: The entrepreneurial University of Waterloo. Research Policy, 37(8), 1175-1187.

Bruneel, J., Spithoven, A., \& Maesen, A. (2007). Building trust: A matter of proximity? Frontiers of Entrepreneurship Research, 27, 1-13.

Bruton, G. D., Ahlstrom, D., \& Li, H. L. (2010). Institutional Theory and Entrepreneurship: Where Are We Now and Where Do We Need to Move in the Future? Entrepreneurship Theory and Practice, 34(3), 421-440.

Bryman, A. (2013). Social Research Methods (3rd ed.). Oxford: Oxford University Press. 
Calcagnini, G., Favaretto, I., Giombini, G., Perugini, F., \& Rombaldoni, R. (2015). The role of universities in the location of innovative start-ups. The Journal of Technology Transfer. doi:10.1007/s10961-0159396-9.

Caprotti, F. (2012). The cultural economy of cleantech: environmental discourse and the emergence of a new technology sector. Transactions of the Institute of British Geographers, 37(3), 370-385.

Carayannis, E., Rogers, E., Kurihara, K., \& Allbritton, M. (1998). High-technology spin-offs from government R\&D laboratories and research universities. Technovation, 18, 1-11.

Chan, K. F., \& Lau, T. (2005). Assessing technology incubator programs in the science park: the good, the bad and the ugly. Technovation, 25(10), 1215-1228. doi:10.1016/j.technovation.2004.03.010.

Chandy, R. K., \& Tellis, G. J. (2000). The incumbent's curse? Incumbency, size, and radical product innovation. The Journal of Marketing, 64(3), 1-17. Retrieved from http://www.jstor.org/stable/ 3203484.

Clarysse, B., \& Moray, N. (2004). A process study of entrepreneurial team formation: The case of a research-based spin-off. Journal of Business Venturing, 19, 55-79.

Cohen, W. M., \& Levinthal, D. A. (1990). Absorptive Capacity: A New Perspective on Learning and Innovation. Administrative Science Quarterly, 35(1), 128-152.

Coleman, J. S. (1988). Social Capital in the Creation of Human Capital. American Journal of Sociology, 94, S95-S120. doi:10.2307/2780243.

Cooper, R. G., \& Kleinschmidt, E. J. (1987). New products: what separates winners from losers? Journal of Product Innovation Management, 4(3), 169-184.

Corbin, J. J. M., \& Strauss, A. (1990). Grounded theory research: Procedures, canons, and evaluative criteria. 13(1). doi:10.1007/BF00988593.

Criscuolo, P., Nicolaou, N., \& Salter, A. (2012). The elixir (or burden) of youth? Exploring differences in innovation between start-ups and established firms. Research Policy, 41(2), 319-333.

D'Este, P., \& Patel, P. (2007). University-industry linkages in the UK: What are the factors underlying the variety of interactions with industry? Research Policy, 36(9), 1295-1313. Retrieved from http://www. sciencedirect.com/science/article/pii/S0048733307001199.

Davidsson, P., \& Honig, B. (2003). The role of social and human capital among nascent entrepreneurs. Journal of Business Venturing, 18(3), 301-331. Retrieved from http://www.sciencedirect.com/science/ article/pii/S0883902602000976.

Davies, A. R. (2013). Cleantech clusters: Transformational assemblages for a just, green economy or just business as usual? Global Environmental Change, 23(5), 1285-1295.

Delmar, F., \& Shane, S. (2003). Does business planning facilitate the development of new ventures? Strategic Management Journal, 24(12), 1165-1185.

Di Gregorio, D., \& Shane, S. (2003). Why do some universities generate more start-ups than others? Research Policy, 32(2), 209-227.

Dollinger, M. J. (1999). Entrepreneurship: Strategies and resources. Boston, MA: Irwin.

Elzen, B., Geels, F. W., \& Green, K. (2004). System innovation and the transition to sustainability: Theory, evidence and policy. Cheltenham: Edward Elgar Publishing.

Etzkowitz, H. (2003). Research groups as "quasi-firms": The invention of the entrepreneurial university. Research Policy, 32(1), 109-121.

Etzkowitz, H. (2004). The evolution of the entrepreneurial university. International Journal of Technology and Globalisation, 1(1), 64-77. Retrieved from http://inderscience.metapress.com/index/ VFP58MEACN34AXNM.pdf.

Etzkowitz, H., \& Leydesdorff, L. (1998). The endless transition: A "Triple Helix" of university-industrygovernment relations. Minerva, 36(3), 271-288.

Etzkowitz, H., \& Leydesdorff, L. (2000). The dynamics of innovation: from National Systems and "Mode 2" to a Triple Helix of university-industry-government relations. Research Policy, 29(2), 109-123.

Etzkowitz, H., Webster, A., \& Healey, P. (1998). Capitalizing knowledge: New intersections of industry and academia. Albany: Suny Press.

Eveleens, C. P., Van Rijnsoever, F. J., \& Niesten, E. (2017). How network-based incubation helps start-up performance: A systematic review against the background of management theories. The Journal of Technology Transfer, 42, 676-713.

Gaglio, C. M., \& Katz, J. A. (2001). The psychological basis of opportunity identification: Entrepreneurial alertness. Small Business Economics, 16(2), 95-111.

Galbreath, J. (2005). Which resources matter the most to firm success? An exploratory study of resourcebased theory. Technovation, 25(9), 979-987.

Gartner, W. B. (1985). A conceptual framework for describing the phenomenon of new venture creation. Academy of Management Review, 10(4), 696-706. 
Gartner, W. B., Bird, B. J., \& Starr, J. A. (1992). Acting as if: Differentiating entrepreneurial from organizational behavior. Entrepreneurship theory and practice, 16(3), 13-31.

Gartner, W. B., \& Vesper, K. H. (1994). Experiments in entrepreneurship education: successes and failures. Journal of Business Venturing, 9(3), 179-187.

Gibbons, M., Limoges, C., Nowotny, H., Schawartzman, S., Scott, P., Trow, M. et al. (1994). The new production of knowledge: The Dynamics of Science and Research in contemporary societies. London: Sage.

Gioia, D. A., Corley, K. G., \& Hamilton, A. L. (2013). Seeking qualitative rigor in inductive research notes on the gioia methodology. Organizational Research Methods, 16(1), 15-31. doi:10.1177/ 1094428112452151.

Göransson, B. (2009). New activities of universities in transfer and extension: Multiple requirements and manifold solutions. Science and Public Policy, 36(2), 157-164.

Göransson, B., Maharajh, R., \& Schmoch, U. (2009). Introduction: New challenges for universities beyond education and research. Science and Public Policy, 36(2), 83-84.

Greene, P. G., Brush, C. G., \& Brown, T. E. (2015). Resources in small firms: An exploratory study. Journal of Small Business Strategy, 8(2), 25-40.

Grimaldi, R., \& Grandi, A. (2005). Business incubators and new venture creation: An assessment of incubating models. Technovation, 25(2), 111-121.

Gubitta, P., Tognazzo, A., \& Destro, F. (2015). Signaling in academic ventures: The role of technology transfer offices and university funds. The Journal of Technology Transfer. doi:10.1007/s10961-0159398-7.

Hager, P., \& Holland, S. (2007). Graduate attributes, learning and employability (Vol. 6). Berlin: Springer.

Hannan, M. T., \& Freeman, J. H. (1984). Structural Inertia and Organizational Change. American Sociological Review, 49(2), 149-164.

Hessels, L. K., \& van Lente, H. (2008). Re-thinking new knowledge production: A literature review and a research agenda. Research Policy, 37(4), 740-760.

Hisrich, R. D., \& Smilor, R. W. (1988). The university and business incubation: Technology transfer through entrepreneurial development. The Journal of Technology Transfer, 13(1), 14-19.

Hovland, I. C., \& Weiss, W. (1951). The Influence of Source Credibility on Communication Effectiveness. Public Opinion Quarterly, 15(4), 635-650. doi:10.1086/266350.

June, M., \& Fargo, W. (2013). U.S. clean tech leadership index. Portland: Clean Edge.

Kaufmann, A., \& Tödtling, F. (2001). Science-industry interaction in the process of innovation: The importance of boundary-crossing between systems. Research Policy, 30(5), 791-804. Retrieved from http://www.sciencedirect.com/science/article/pii/S0048733300001189.

Kilby, P. (1971). Hunting the heffalump. Entrepreneurship and Economic Development, 1-40.

Kristandl, G., \& Bontis, N. (2007). Constructing a definition for intangibles using the resource based view of the firm. Management Decision, 45(9), 1510-1524.

Lackéus, M., \& Williams Middleton, K. (2015). Venture Creation Programs: bridging entrepreneurship education and technology transfer. Education + Training, 57(1), 48-73.

Latour, B., \& Woolgar, S. (1979). Laboratory life: The social construction of scientific facts. London: Princeton University Press.

Lee, Y. S. (1996). "Technology transfer" and the research university: A search for the boundaries of university-industry collaboration. Research Policy, 25(6), 843-863.

Levie, J. (2014). The university is the classroom: Teaching and learning technology commercialization at a technological university. The Journal of Technology Transfer, 39(5), 1-16.

Liao, J., \& Welsch, H. (2008). Patterns of venture gestation process: Exploring the differences between tech and non-tech nascent entrepreneurs. The Journal of High Technology Management Research, 19(2), 103-113. doi:10.1016/j.hitech.2008.10.003.

Lin, Z., Yang, H., \& Arya, B. (2009). Alliance partners and firm performance: Resource complementarity and status association. Strategic Management Journal, 30(9), 921-940. doi:10.1002/smj.773.

Lincoln, Y. S., \& Guba, E. G. (2013). The constructivist credo. Walnut Creek: Left Coast Press.

Link, A. N., \& Scott, J. T. (2005). Opening the ivory tower's door: An analysis of the determinants of the formation of US university spin-off companies. Research Policy, 34(7), 1106-1112.

MacMillan, I. C., Zemann, L., \& Subbanarasimha, P. N. (1987). Criteria distinguishing successful from unsuccessful ventures in the venture screening process. Journal of Business Venturing, 2(2), 123-137.

Marmer, M., Herrmann, B. L., Dogrultan, E., Berman, R., Eesley, C., \& Blank, S. (2012). The startup ecosystem report 2012. Startup Genome: Technical report.

McAdam, M., \& McAdam, R. (2008). High tech start-ups in University Science Park incubators: The relationship between the start-up's lifecycle progression and use of the incubator's resources. Technovation, 28(5), 277-290. doi:10.1016/j.technovation.2007.07.012. 
Medda, G., Piga, C., \& Siegel, D. S. (2004). University R\&D and firm productivity: Evidence from Italy. The Journal of Technology Transfer, 30(1-2), 199-205.

Meyer-Krahmer, F., \& Schmoch, U. (1998). Science-based technologies: university-industry interactions in four fields. Research Policy, 27(8), 835-851.

Mian, S. A. (1996). Assessing value-added contributions of university technology business incubators to tenant firms. Research Policy, 25(3), 325-335.

Mueller, P. (2006). Exploring the knowledge filter: How entrepreneurship and university-industry relationships drive economic growth. Research Policy, 35(10), 1499-1508.

Nowotny, H., Scott, P., \& Gibbons, M. (2003). Introduction: Mode 2'Revisited: The New Production of Knowledge. Minerva, 41(3), 179-194.

Park, J. S. (2005). Opportunity recognition and product innovation in entrepreneurial hi-tech start-ups: A new perspective and supporting case study. Technovation, 25(7), 739-752.

Perkmann, M., Tartari, V., McKelvey, M., Autio, E., Broström, A., D’Este, P., et al. (2013). Academic engagement and commercialisation: A review of the literature on university-industry relations. $R e$ search Policy, 42(2), 423-442.

Pirnay, F., \& Surlemont, B. (2003). Toward a typology of university spin-offs. Small Business Economics, 21(4), 355-369.

Pornpitakpan, C. (2004). The Persuasiveness of Source Credibility: A Critical Review of Five Decades' Evidence. Journal of Applied Social Psychology, 34(2), 243-281. doi:10.1111/j.1559-1816.2004. tb02547.x.

Powers, J. B. (2003). Commercializing academic research: Resource effects on performance of university technology transfer. The Journal of Higher Education, 74(1), 26-50.

Powers, J. B., \& McDougall, P. P. (2005). University start-up formation and technology licensing with firms that go public: a resource-based view of academic entrepreneurship. Journal of Business Venturing, 20(3), 291-311.

Rahm, D. (1994). Academic Perceptions of University-Firm Technology Transfer. Policy Studies Journal, 22(2), 267-278.

Rasmussen, E., \& Wright, M. (2015). How can universities facilitate academic spin-offs? An entrepreneurial competency perspective. The Journal of Technology Transfer, 40(5), 782-799. doi:10.1007/s10961014-9386-3.

Ratinho, T., \& Henriques, E. (2010). The role of science parks and business incubators in converging countries: Evidence from Portugal. Technovation, 30(4), 278-290. doi:10.1016/j.technovation.2009.09. 002 .

Ready, K. (2012). Paying it forward: Silicon valley's open secret to success. Forbes Magazine. Retrieved from http://www.forbes.com/sites/kevinready/2012/08/23/paying-it-forward-silicon-valleys-opensecret-to-success/.

Reynolds, P., \& Miller, B. (1992). New firm gestation: Conception, birth, and implications for research. Journal of Business Venturing, 7(5), 405-417.

Ries, E. (2011). The lean startup: How today's entrepreneurs use continuous innovation to create radically successful businesses. New York: Random House LLC.

Roessner, D., Ailes, C. P., Feller, I., \& Parker, L. (1998). How industry benefits from NSF's Engineering Research Centers. Research technology management, 41(5), 40-44.

Rosenberg, N. (1994). Exploring the black box: Technology, economics, and history.

Rosenberg, N., \& Nelson, R. R. (1994). American universities and technical advance in industry. Research Policy, 23(3), 323-348.

Rothaermel, F. T., Agung, S. D., \& Jiang, L. (2007). University entrepreneurship: A taxonomy of the literature. Industrial and Corporate Change, 16(4), 691-791.

Rothaermel, F. T., \& Thursby, M. (2005a). University-incubator firm knowledge flows: Assessing their impact on incubator firm performance. Research Policy, 34(3), 305-320. doi:10.1016/j.respol.2004.11. 006.

Rothaermel, F. T., \& Thursby, M. (2005b). Incubator firm failure or graduation?: The role of university linkages. Research Policy, 34(7), 1076-1090.

Santoro, M. D., \& Chakrabarti, A. K. (2002). Firm size and technology centrality in industry-university interactions. Research Policy, 31(7), 1163-1180. Retrieved from http://www.sciencedirect.com/ science/article/pii/S0048733301001901

Saxenian, A. (1996). Regional advantage: Culture and competition in Silicon Valley and Route 128. Cambridge: Harvard Univerisity Press.

Schartinger, D., Schibany, A., \& Gassler, H. (2001). Interactive relations between universities and firms: Empirical evidence for Austria. The Journal of Technology Transfer, 26(3), 255-268. 
Schulte, P. (2004). The entrepreneurial university: A strategy for institutional development. Higher Education in Europe, 29(2), 187-191.

Schumpeter, J. A. (1942). Socialism, capitalism and democracy. New York: Harper and Brothers.

Scillitoe, J. L., \& Chakrabarti, A. K. (2010). The role of incubator interactions in assisting new ventures. Technovation, 30(3), 155-167.

Shane, S. (2000). Prior knowledge and the discovery of entrepreneurial opportunities. Organization Science, 11(4), 448-469.

Shane, S., \& Cable, D. (2002). Network ties, reputation, and the financing of new ventures. Management Science, 48(3), 364-381.

Siegel, D. S. (2006). Technology entrepreneurship: Institutions and agents involved in university technology transfer (Vol. 1). London: Edgar Elgar.

Soetanto, D., \& Jack, S. (2016). The impact of university-based incubation support on the innovation strategy of academic spin-offs. Technovation, 50, 25-40.

Stam, E. (2015). Entrepreneurial ecosystems and regional policy: A sympathetic critique. European Planning Studies, 23(9), 1759-1769.

Sternthal, B., Ruby, D., \& Leavitt, C. (1978). The persuasive effect of source credibility: Tests of cognitive response. Journal of Consumer Research, 4(4), 252-260. Retrieved from http://www.jstor.org/stable/ 2488816.

Thorsteinsdóttir, O. (2000). External research collaboration in two small science systems. Scientometrics, 49, $145-160$.

Trott, P. (2008). Innovation management and new product development. London: Pearson Education.

van Geenhuizen, M., \& Soetanto, D. P. (2009). Academic spin-offs at different ages: A case study in search of key obstacles to growth. Technovation, 29(10), 671-681. doi:10.1016/j.technovation.2009.05.009.

Van Rijnsoever, F. J., Hessels, L. K., \& Vandeberg, R. L. J. (2008). A resource-based view on the interactions of university researchers. Research Policy, 37(8), 1255-1266.

Van Rijnsoever, F. J., Welle, L., \& Bakker, S. (2014). Credibility and legitimacy in policy-driven innovation networks: Resource dependencies and expectations in Dutch electric vehicle subsidies. The Journal of Technology Transfer, 39(4), 635-661.

Van Weele, M. A., Van Rijnsoever, F. J., \& Nauta, F. (2017). You Can't Always Get What You Want: How Entrepreneur's Perceived Resource Needs Affect the Incubator's Assertiveness. Technovation, 59, 18-33.

Van Weele, M. A., Van Rijnsoever, F. J., Eveleens, C. P., Steinz, H. J., Van Stijn, N., \& Groen, M. (n.d.). Start-EU-up! International incubation practices to address the main challenges of the Western European entrepreneurial ecosystem. The Journal of Technology Transfer.

Vesper, K. H. (1990). New venture strategies. In University of Illinois at Urbana-Champaign's Academy for Entrepreneurial Leadership Historical Research Reference in Entrepreneurship.

Vohora, A., Wright, M., \& Lockett, A. (2004). Critical junctures in the development of university high-tech spinout companies. Research Policy, 33(1), 147-175. doi:10.1016/S0048-7333(03)00107-0.

Von Hippel, E. (2007). The sources of innovation. Berlin: Springer.

Wang, C. L., \& Chugh, H. (2014). Entrepreneurial learning: Past research and future challenges. International Journal of Management Reviews, 16(1), 24-61.

Wenger, E. (1998). Community of practice. Cambridge: Cambridge University. 